\title{
The 600 year eruptive history of Villarrica Volcano (Chile) revealed by annually-laminated lake sediments
}

Van Daele, M. ${ }^{1}$, Moernaut, J. ${ }^{2,1}$, Silversmit, G. ${ }^{3}$, Schmidt, S. ${ }^{4}$, Fontijn, K. ${ }^{5}$, Heirman, K. ${ }^{1}$, Vandoorne, W. ${ }^{1}$, De Clercq, M. ${ }^{1}$, Van Acker, J. $^{6}$, Wolff, C. ${ }^{7}$, Pino, ${ }^{1}{ }^{8}$, Urrutia, R. ${ }^{\text {, }}$ Roberts, S.J. ${ }^{10}$, Vincze, L. $^{3}$ and De Batist, M. ${ }^{1}$

${ }^{1}$ Renard Centre of Marine Geology (RCMG), Department of Geology and Soil Science, Ghent University, Krijgslaan 281/S8, B-9000 Gent, Belgium.

${ }^{2}$ Geological Institute, ETH Zürich, Sonneggstrasse 5, 8092 Zürich, Switzerland.

${ }^{3}$ X-ray Microspectroscopy and Imaging Group (XMI), Department of Analytical Chemistry, Ghent University. Krijgslaan 281/S12, B-9000 Gent, Belgium.

${ }^{4}$ Environnements et Paléoenvironnements Océaniques (EPOC), CNRS, Université Bordeaux 1, Avenue des facultés, 33405 Talence cedex, France.

${ }^{5}$ Department of Earth Sciences, University of Oxford, South Parks Road, Oxford, OX1 3AN, $U K$.

${ }^{6}$ Department Forest and Water Management, Ghent University, Coupure Links 653, B-9000 Gent, Belgium.

${ }^{7}$ Helmholtz Centre Potsdam GeoForschungsZentrum (GFZ-German Research Centre for Geosciences), Section 5.2 - ClimateDynamics and Landscape Evolution, Telegrafenberg, D14473 Potsdam, Germany.

${ }^{8}$ Instituto de Geociencias, Universidad Austral de Chile, Casilla 567, Isla Teja, Valdivia, Chile.

${ }^{9}$ Centro EULA, Universidad de Concepción, Casilla 160-C, Concepción, Chile.

${ }^{10}$ British Antarctic Survey (BAS), High Cross, Madingley Road, Cambridge, CB3 OET United Kingdom.

\section{KEYWORDS}

$\mu \mathrm{XRF}$; turbidite; lahar; Calafquén; Villarrica

\begin{abstract}
Lake sediments contain valuable information about past volcanic and seismic events that have affected the lake catchment, and provide unique records of the recurrence interval and magnitude of such events. This study uses a multi-lake and multi-proxy analytical approach to obtain reliable and high-resolution records of past natural catastrophes from c. 600 year old annually-laminated (varved) lake sediment sequences extracted from two lakes, Villarrica and Calafquén, in the volcanically and seismically active Chilean Lake District. Using a combination of $\mu$ XRF scanning, microfacies analysis, grain-size analysis, color analysis and magnetic-susceptibility measurements, we detect and characterize four different types of event
\end{abstract}


deposits (EDs) (lacustrine turbidites; tephra-fall layers; runoff cryptotephras; lahar deposits) and produce a revised eruption record for Villarrica Volcano, which is unprecedented in its continuity and temporal resolution. Glass geochemistry and mineralogy also reveal deposits of eruptions from the more remote Carrán-Los Venados Volcanic Complex, Quetrupillán Volcano and the Huanquihue Group in the studied lake sediments. Time series analysis shows 112 eruptions with a Volcanic Explosivity Index (VEI) $\geq 2$ from Villarrica Volcano in the last c. 600 years, of which at least 22 also produced lahars. This significantly expands our knowledge on the eruptive frequency of the volcano in this time window, compared to the previously known eruptive history from historical records. The last VEI $\geq 2$ eruption of Villarrica Volcano occurred in 1991. We estimate the probability of the occurrence of future eruptions from Villarrica Volcano, and statistically demonstrate that the probability of a 22-year repose period (anno 2013) without VEI $\geq 2$ eruptions is $\leq 1.7 \%$. This new perspective on the recurrence interval of eruptions and historical lahar activity will help improve volcanic hazard assessments for this rapidly expanding tourist region, and highlights how lake records can be used to significantly improve historical eruption records in areas that were previously uninhabited.

\section{INTRODUCTION}

The unforeseen eruption of Chaitén Volcano in 2008 (Carn et al., 2009; Lara, 2009; Watt et al., 2009) and the unanticipated magnitude of the 2010 Maule earthquake $\left(\mathrm{M}_{\mathrm{w}} 8.8\right)$ (Ruegg et al., 2009) illustrate how little is still known about the recurrence intervals, modes and magnitudes of such catastrophic natural events in Chile. To assess these parameters, reliable records of past catastrophes (e.g., earthquakes, volcanic eruptions and floods) are of vital importance. Unfortunately, historical accounts of such events are limited in time, and often incomplete and unreliable, especially in remote regions. To make robust probability estimates of repose times and improve hazard assessments, new and better-resolved time series of past earthquakes and eruption events, and their impacts are needed.

An eruption record can be established by tephrostratigraphic studies in the area near the volcano. However, classic tephrostratigraphic studies, such as the ones presented for southern Patagonia by Stern (2008) or for the Hualaihue region by Watt et al. (2011), are, as a result of terrestrial preservation constraints, typically limited to relatively large-scale eruptions with regionally widespread tephra-fall deposits, ignimbrites and/or voluminous lava flows. Establishing a well-dated record of relatively small-scale but locally significant eruption events, which produce less substantial tephra deposits, remains a major challenge and is often biased towards the available historical record (e.g., Dzierma and Wehrmann, 2010). Between events, erosion and soil formation can alter terrestrial deposits, while lahars often re-use the same pathways during subsequent events, eroding older deposits (Naranjo and Moreno, 2004). Therefore, a new type of dataset is required, one that can improve both the temporal and spatial resolution of the eruption record as well as incorporate smaller eruption events.

In comparison to subaerial environments, sediment deposition in lakes is relatively constant and often continuous. In Lake Puyehue, located in the Chilean Lake District, hemipelagic sediments (henceforth referred to as background sedimentation) are annually laminated (varved) between volcanic events (Boës and Fagel, 2008), providing robust age control. Lake sediments also integrate the response of processes affecting (parts of) the catchment. For example, volcanic ash layers and lahar (i.e. mudflow composed of volcaniclastic 
material) deposits (henceforth referred to as event deposits or EDs) are often deposited in the catchment, but not always directly into the lake. These EDs are usually washed into the lake during subsequent rainfall events; hence, the lake sediments have the potential to contain a record of all eruptions that affected the lake's catchment. Records from several lakes, whose combined catchments are influenced by the entire volcano, potentially provide a complete eruption record for that particular volcano.

EDs recorded in lacustrine sediments can sometimes be subtle features, represented by only very fine laminae (100-200 $\mu \mathrm{m}$ thick), and traditional sedimentological techniques are therefore often inadequate for their identification and analysis. In contrast, $\mu$ XRF scanning and geochemical mapping (Kylander et al., 2011 and references therein) have proven to be very useful in detecting and characterizing very thin EDs in impregnated sediment slabs of annually laminated sediments, thereby providing a powerful technique, especially when cross-validated by independent methodologies (Katsuta et al., 2007).

In this study, we applied $\mu \mathrm{XRF}$ scanning in combination with magnetic susceptibility (MS) and color, grain-size and microfacies analysis to varve-counted sediment cores extracted from two lakes in the Chilean Lake District of South-Central Chile. We also used electron microprobe major element data on selected tephra-fall layers to support inter-lake correlations. Our aims are to: 1) detect, characterize and classify EDs; 2) determine ED formation processes; 3) establish a new, high-resolution eruptive history for Villarrica Volcano; and 4) use statistical analysis to establish a new eruption time series for Villarrica Volcano and provide estimates of the probability of future eruptions. From this point forward, all dates are AD.

\section{REGIONAL SETTING}

\subsection{Site description}

Lake Villarrica (214 m asl, 21 x 9 km) and Lake Calafquén (204 m asl, 24 x 2-6 km) are two large glacigenic lakes situated at the foot of the Chilean Andes between $39^{\circ}$ and $40^{\circ} \mathrm{S}$ (Fig. 1). Both lakes lie in glacially overdeepened valleys dammed at their western border by large frontal moraines of late Pleistocene age. The present-day climate in this part of Chile is humidtemperate and vegetation consists of predominantly evergreen deciduous (rain)forest. The tree line is located at 1500-1700 m, but can be lower on the (active) volcanoes, of which the upper slopes are mainly covered by lava flows. Valleys and other lower areas (especially towards the west) are used for agriculture and are predominantly covered by grassland (Fig. 1). The soils in the study area are andosols that developed in volcanic ash. Amorphous clays (allophanes) are the product of post-depositional weathering of this ash, which mainly consists of glass and plagioclase crystals (Bertrand and Fagel, 2008). Precipitation mainly occurs during austral winter, driven by the southern Westerlies (Heusser, 2003) (in the town of "Villarrica": 1600 mm from April through September; Dirección General de Aguas, Chile, unpublished data; see Suppl. Fig. 1) and is slightly reduced in El-Niño years (Suppl. Fig. 1). The perennially high amount of winter precipitation and overall dense vegetation cover suggests that the availability of easily erodible material in the sediment catchment (i.e. the part of the drainage basin that drains directly to the lake, without other lakes functioning as sediment traps in between) is the controlling factor on sediment transport to the lakes. 
Lake Villarrica has a large sediment catchment $\left(2650 \mathrm{~km}^{2}\right)$ comprising the northern slopes of Villarrica, Quetrupillán and Lanín volcanoes and the southern slopes of Sollipulli Volcano (Fig. 1). The Trancura River is its main tributary. Lake Villarrica is a warm monomictic lake, in which the thermocline has a depth of a few meters in spring, developing to $\sim 20 \mathrm{~m}$ in summer and $\sim 70 \mathrm{~m}$ in autumn due to partial mixing, followed by complete mixing in winter (Campos et al., 1983).

Lake Calafquén has a smaller sediment catchment $\left(554 \mathrm{~km}^{2}\right)$ comprising the southern slopes of Villarrica Volcano and the southwestern slopes of Quetrupillán Volcano (Fig. 1). The Llancahue River is its main tributary. The thermal regime of Lake Calafquén appears to be similar to that of Lake Villarrica, at least in summer (Geller, 1992).

\subsection{Geology and eruptive history}

Villarrica Volcano (39 $25^{\prime} 12^{\prime}$ 'S , 71 ${ }^{\circ} 56^{\prime} 23^{\prime}$ 'W, $2847 \mathrm{~m}$ asl; Fig. 1) is a composite Pleistocene-Holocene stratovolcano comprised of a late Pleistocene caldera with an internal late Holocene cone. Its products are of basaltic to andesitic composition (e.g., Lara, 2004). There has been frequent recorded volcanic activity since the arrival of the Spanish colonists in 1551, and it is one of the most active volcanoes in South America. Its first reported eruption, in 1558, destroyed the town of "Villarrica", which was located at the present location of Pucón (Fig. 1). The town was rebuilt at its present location, but was abandoned from 1602 to 1882, due to a war between the Spanish colonists and the Mapuche, the native inhabitants of Southern Chile. As a result, there is a lack of historical reports for this period. From 1750 to 1882, the area was gradually repopulated by Spanish colonists and reports of volcanic eruptions become more common and reliable (Petit-Breuilh, 2004). Records of 20th century eruptions are more or less complete, and show that Villarrica, in its most recent history, produced lava flows, relatively small-scale pyroclastic falls and, more importantly, lahars capable of destroying infrastructure. For example, in 1964, lahars generated during an eruption destroyed the village of Coñaripe (Fig. 1; Petit-Breuilh, 2004; González-Ferrán, 1994; Urrutia de Hazbún and Lanza Lazcano, 1993; Naranjo and Moreno, 2004; Keller et al., 2008, Castruccio et al., 2010). These lahars originate in the snow-covered upper slopes of the volcano and further develop (i.e. grow by further erosion) on non-vegetated slopes (Fig. 1). Most of their deposits are found on the lower, more gentle slopes (Castruccio et al., 2010). Many 20th-century eruptions caused fatalities, and rapidly expanding tourist activity in the region is increasing the risk of future fatalities, as well as destruction of property.

No historical eruptions of the nearby Sollipulli or Lanín volcanoes have been recorded and depending on the source only one to four historical eruptions have been reported for Quetrupillán Volcano, all in the 19th century (Fig. 1; Petit-Breuilh, 2004; Siebert et al., 2010).

The Huanquihue Group is located southeast of the study area, and it has had one known historical eruption (Achen Niyeu cinder cone), which was dated to 200 (Siebert et al., 2010) to $\sim 400$ (local sources) years ago. More active and distant volcanoes $(<100 \mathrm{~km})$ are Llaima Volcano in the north, and the Mocho-Choshuenco Volcano, Carrán-Los Venados and Puyehue - Cordón Caulle volcanic complexes in the south (Fig. 1; Petit-Breuilh, 2004; Siebert et al., 2010).

\subsection{Tectonic and seismic history}


Volcano-tectonic processes in this region are a consequence of the oblique subduction of the Nazca Plate under the South-American Plate. The current convergence rate between these two plates is estimated between $66 \mathrm{~mm} / \mathrm{y}$ (Angermann et al., 1999) and $78 \mathrm{~mm} / \mathrm{y}$ (DeMets et al., 1994). The plate boundary has produced numerous megathrust earthquakes. For example, the 1960 Great Chilean Earthquake along the Valdivia segment (Metois et al., 2012) was to this date the largest earthquake ever recorded instrumentally $\left(\mathrm{M}_{\mathrm{w}} 9.5\right)$ and had a rupture length of $1000 \mathrm{~km}$ (Cifuentes, 1989). Other major historical earthquakes along the Valdivia segment occurred in 1575, 1737 and 1837. The effects of the 1575 earthquake were similar to those of the 1960 earthquake (Lomnitz, 1970; Lomnitz, 2004; Cisternas et al., 2005). On 27th February 2010, the Maule earthquake $\left(\mathrm{M}_{\mathrm{w}} 8.8\right)$ ruptured about $500 \mathrm{~km}$ of the megathrust and closed a seismic gap on the Maule segment (Metois et al., 2012), just north of the Valdivia segment (Moreno et al., 2012).

Additionally, the Liquiñe-Ofqui Fault Zone (LOFZ) is a 1000-km-long, dextral strikeslip lineament, which has been accommodating the oblique subduction since the Middle Miocene. The fault zone separates the north-moving $(6.5 \mathrm{~mm} / \mathrm{y})$ Chiloé sliver (in the west) from the rest of the South-American Plate (in the east) (Cembrano et al., 2000; Wang et al., 2007; Melnick et al., 2009). In the study area, the main strand of the fragmented LOFZ runs about 10$20 \mathrm{~km}$ to the east of Villarrica Volcano (Fig. 1; Rosenau et al., 2006; Cembrano and Lara, 2009).

\section{METHODOLOGY}

\subsection{Bathymetry and seismic data acquisition}

Dense grids of seismic data were acquired using a $3.5 \mathrm{kHz}$ sub-bottom profiler (pinger) and a CENTIPEDE sparker of the Renard Centre of Marine Geology (Ghent University; Suppl. Figs. 2 and 3) and were interpreted using SMT's KingdomSuite (more details can be found in Moernaut et al. (2009)).

Bathymetric maps were constructed by means of interpolation between seismic data (acoustic velocity derived by depth measurements at coring sites; Moernaut et al., 2009) and data points of bathymetric soundings of the Servicio Hidrográfico y Oceanográfico de la Armada de Chile (SHOA, 1987; 2008).

\subsection{Sedimentology, geochemistry and chronology}

In this study, we present 22 gravity cores $(10-130 \mathrm{~cm})$ from both studied lakes using a Swiss corer or a UWITEC gravity corer (Suppl. Table 1). Cores were taken during the austral summers of 2007-2008 (CAGC), 2008-2009 (CB, CGC and VILLSC) and 2010-2011 (CALA and VI). Cores were shipped to Belgium, opened, described and photographed. Subsequently, the magnetic susceptibility (MS) was measured on all cores. The employed methods are briefly described in this section. More detailed descriptions can be found as supplementary material.

For each lake, one master core, which contain EDs that are not -or to a limited extenterosional, was selected for more detailed analysis (i.e. VILLSC01 (Lake Villarrica), CAGC02bis (Lake Calafquén)). Color analysis, analysis of grain-size distribution and of organic-matter content, and Scanning Electron Microscope (SEM) imaging were performed at Ghent University using standard procedures. On selected samples bulk X-Ray Diffraction (XRD) was performed to determine the different sediment mineral components. On a selection 
of tephra layers, glass major element geochemistry and mineral compositions were determined using electron microprobe analysis and SEM-EDS at the University of Oxford. The master cores also were impregnated for microscopic analyses. On the sediment blocks, Micro-X-ray Fluorescence ( $\mu \mathrm{XRF})$ scanning and mapping was used to differentiate between Si-rich diatoms, Al-rich clays, fine detrital silts and Fe-rich tephras. Furthermore, the thin sections and sediment blocks were used for microfacies analysis and lamination/varve counting. Finally, radionuclide dating was performed on the upper part of core CAGCO2bis at the Université de Bordeaux (for more detailed information, see Supplementary Material).

\section{RESULTS AND DISCUSSION}

\subsection{Bathymetry and core location}

The bathymetry of both studied lakes is characterized by a deep basin and a shallower area with platforms and sub-basins. The deep basins occur in the eastern or northern parts of the lakes, have deltaic fans linked to the main inflows and are usually delimited by steep, nonsediment-bearing slopes. The shallower areas, where most of the cores were taken, occur in the western or southwestern parts of the lakes, away from the main inflows.

Lake Villarrica has a maximum depth of about $165 \mathrm{~m}$, in the central to northwestern part of the lake (Fig. 2). In the east and the south of the deep basin gentle slopes $\left(<0.5^{\circ}\right)$ rise towards the coastlines and the deltas. Six cores were taken in the southern part of this main basin; in the east it was not possible to retrieve cores due to the presence of coarse-grained sediments (i.e. coarse sand). Five more cores are located on the platforms and sub-basins in the southwestern part of the lake. Reflection-seismic data show that on the core locations there are no signs of erosion or other disturbances in the upper meters of the sedimentary infill (Suppl. Fig. 2). We only found evidence of an erosional channel east of VI13, linked to one of the largest lahar inflows on the southern shores (Suppl. Fig. 2).

The maximum depth of Lake Calafquén is about $211 \mathrm{~m}$ and is located in the northern part of the lake (Fig. 3). The depth gradually decreases towards the east to a depth of about 170 $\mathrm{m}$ at the foot of the Llancahue River delta. Four cores were taken in these deepest areas of the lake. Large water depth and coarse sediments did not permit coring in the northwestern and northeastern parts, respectively. In the northeast, offshore the Chaillupén River inlet, a fan-like structure with no seismic penetration is observed. Unsuccessful coring attempts in this area make us attribute this lack of penetration to the presence of sandy sediments. Seven cores were taken in the southwestern part of the lake, which is characterized by an irregular bathymetry with several sub-basins and platforms, interrupted by islands. CALA01 was taken in a channel with parallel and conformable reflectors in the upper meters. All other cores were taken on locations without erosional features (Suppl. Fig. 3).

\subsection{Sedimentology and geochemistry}

In all cores, the predominantly biogenic (background) sediments consist of laminated brown to green coarse to very coarse silts (Fig. 4 and Suppl. Fig. 4). The sediment is composed of a silt fraction rich in diatom frustules and a terrigenous clay to silt fraction. After impregnation, couplets composed of diatom-enriched laminae alternating with clay and organic matter-enriched laminae were observed in thin section (central column of Suppl. Fig. 4). 
The three main components of the sediment (i.e. diatom frustules, terrestrial clays and volcanic ash) are characterized by high concentrations of specific chemical elements (i.e. respectively $\mathrm{Si}, \mathrm{Al}$ and $\mathrm{Fe}$ ), which is reflected in the $\mu \mathrm{XRF}$ elemental counts. Diatom frustules are composed of amorphous silica and characterized by high Si-counts on the $\mu$ XRF spectra and a low MS. In contrast, the clay fraction consists mainly of amorphous allophane, which is enriched in Al (Bertrand and Fagel, 2008), and a distinctive elemental component of mafic volcanic ash, such as the ash from Villarrica Volcano, is Fe. Hence, ratios between these three elements were used to depict variations in occurrence of diatom frustules, terrestrial clays and volcanic ash in the sediment (Fig. 4).

In both studied lakes, the laminated background sediments are frequently interrupted by volcanically derived EDs, in which terrestrial components produced by onshore events occur in unusually high abundance. $\mathrm{Al} / \mathrm{Si}$ and $\mathrm{Fe} / \mathrm{Si} \mu \mathrm{XRF}$ ratios proved particularly useful for separating these EDs from background sediment in the studied lakes (Fig. 4).

The two lakes differ in their sediment character, requiring an adapted study method for each lake. In Lake Calafquén, which has a low catchment-to-lake-surface ratio, the background sediments consist predominantly of diatoms; hence, there is a strong contrast between the diatom-rich background sediment and the detrital EDs. Lake Villarrica generally receives higher amounts of detrital input. Small mineral grains and glass particles are present throughout the background sediment, resulting in higher mean MS values and $\mathrm{Al} / \mathrm{Si}$ and $\mathrm{Fe} / \mathrm{Si}$ ratios. This makes EDs more difficult to identify by their $\mu \mathrm{XRF}$ signature alone; hence, other indicators (normal grading, homogeneity of color and grain size and/or anomalous color) were also used to confirm the presence of EDs.

\subsection{Varve formation and chronology}

The couplets that are observed in the background sediment of both studied lakes are interpreted as varves, formed by processes similar to those that generate varve couplets observed in Lake Puyehue. Lake Puyehue is also a glacigenic lake, approximately $120 \mathrm{~km}$ south of Lake Calafquén (Fig. 1 A), with limnological characteristics similar to the lakes studied here (Campos et al., 1983; 1989). In Lake Puyehue, annual biogenic varve couplets are composed of a lamina of organic-rich clayey to silty terrestrial material depositing during increased winter runoff, and a lamina of diatom frustules deposited in spring; the latter result from diatom blooms that are triggered by winter nutrient turn-over (Arnaud et al. 2006; Boës and Fagel, 2008; Campos et al., 1989). Similar couplets are observed in this study and are therefore inferred to have been formed in the same way and deposited annually.

In both studied lakes, one master core was dated by varve counting (i.e. VILLSC01 in Villarrica and CAGC02bis in Calafquén; Suppl. Figs. 5 and 6). The calculated average sedimentation rates, after removal of EDs are 1.53 and $1.04 \mathrm{~mm} / \mathrm{yr}$, respectively, and the basal varve ages are 1523 and 1325, respectively. In both lakes the sediment deposited after 1900 has a darker color than that deposited before 1900, a higher organic-matter content and a different diatom composition, which is reflected in the grain-size mode (Fig. 4). We attribute these synchronous changes in sediment characteristics to rapid increases in population, deforestation, changes in land use in the catchment since the start of the 20th century (Petit-Breuilh, 2004).

Core CAGC02bis was also dated by radionuclide analysis $\left({ }^{210} \mathrm{~Pb}\right.$ and ${ }^{137} \mathrm{Cs}$; Fig. 4). In the upper $5 \mathrm{~cm}$, samples were taken at $0.5 \mathrm{~cm}$ intervals between EDs, whereas below this depth 
samples were taken at $1.0 \mathrm{~cm}$ intervals. At $4.0-4.5 \mathrm{~cm}$ corrected depth (i.e. depth without EDs) a clear ${ }^{137}$ Cs-peak can be observed, which gradually decreases in the overlying samples. The base of the ${ }^{137} \mathrm{Cs}$-peak can be linked to fall-out of the ${ }^{137} \mathrm{Cs}$ that had culminated in the atmosphere by the early 1960s (Arnaud et al., 2006; Von Gunten et al., 2009) and confirms the varve-age at this depth. This correlation is strengthened by the ${ }^{210} \mathrm{~Pb}_{\mathrm{xs}}$ specific activity and agedepth profile with a derived sedimentation rate of $0.95 \mathrm{~mm} / \mathrm{y}$ throughout the last 100 years. The age-depth model based on the radionuclide activities confirms the annual character of the couplets and hence their usefulness in dating the rest of the core. The maximum offset between both age-depth models is 5 calendar years near the EDs, which is likely due to imperfect removal of the EDs, and only 2 years in intervals without EDs. The varve counting is therefore considered to be a sufficiently reliable dating method.

\subsection{Event deposit classification and formation}

Based on color, grain-size characteristics, MS, $\mu$ XRF signature and microscopic texture, we divided EDs in both lakes into two main types: lacustrine turbidites and volcanic-eruptioninduced EDs. Volcanic-eruption-induced EDs were further subdivided into three groups: tephra fall, Fe-rich clay to fine silt laminae (FeLs), and detrital fining-upwards EDs (interpreted as lahar deposits). The EDs were also correlated between the sediment cores of each lake (Figs. 2 and 3), allowing us to describe the deposits not only based on occurrence in one core, but also to describe their spatial distribution and variations (e.g., thickness, grain size), and to detect possible erosion.

\section{i) Lacustrine turbidites}

Lacustrine turbidites have a thickness ranging from a few millimeters to several centimeters. They are normally graded, with the largest changes in grain size occurring at the base and at the top (Fig. 4). The basal component is at most a few millimeters thick and consists of fine to coarse sand. The top component is maximum a few millimeters thick and consists of a lamina of broken diatoms (low Al/Si ratio), covered by fine silts and clays (high $\mathrm{Al} / \mathrm{Si}$ and $\mathrm{Fe} / \mathrm{Si}$ ratios). The middle (and main) part of the turbidite is homogeneous in grain size and sometimes darker than the background sediment. The composition of this part is similar to the background sediment (i.e., a mixture of (broken) diatoms, clays, organic matter and mineral/glass particles), which is also reflected in grain size (mode: 20-30 $\mu \mathrm{m}$ ) and $\mu \mathrm{XRF}$ elemental counts $(0.011<\mathrm{Al} / \mathrm{Si}<0.062 ; 0.29<\mathrm{Fe} / \mathrm{Si}<1.50$; Fig. 4 and Suppl. Fig. 4). The similarity in composition suggests that these EDs are distal turbidites created by sublacustrine slope failures. By inter-core correlation, it was possible to verify that the base is rarely erosional, or that erosion is limited to some millimeters. Only lacustrine turbidite LT-1 in core CALA01, located in a channel, erodes about $10 \mathrm{~cm}$ of underlying sediment (Fig. 3). Similar turbiditic EDs have been found in other Andean and Alpine lakes where they have been used as paleoseismic indicators (Chapron et al., 2006, Bertrand et al., 2008a; Beck, 2009).

\section{ii) Volcanic-eruption induced EDs}

a) Tephra-fall layers. The tephra-fall layers typically consist of dark, coarse-grained (fine to coarse sand, i.e. medium/coarse ash) glass shards and mineral grains (mainly plagioclase, clinopyroxene, olivine and Ti-magnetite) in a matrix of background sediment (Suppl. Fig. 4). Deposits are usually not thicker than $5 \mathrm{~mm}$ and are characterized by higherthan-background $\mathrm{Al} / \mathrm{Si}$ and especially $\mathrm{Fe} / \mathrm{Si}$ ratios $(\mathrm{Al} / \mathrm{Si}>0.062, \mathrm{Fe} / \mathrm{Si}>1.50$; Fig. 4). The 
strong scatter is attributed to coarse ash grains influencing the average composition and background sediment acting as a matrix. The thickness of the deposits at different locations in one lake is independent of the water depth, suggesting they result from direct tephra fallout on the lake surface. EDs with similar characteristics have been attributed to tephra fallout in nearby lakes Puyehue (40 $\left.40^{\prime} \mathrm{S}, 72^{\circ} 28^{\prime} \mathrm{W}\right)$ and Icalma (38 $\left.48^{\prime} \mathrm{S}, 71^{\circ} 17^{\prime} \mathrm{W}\right)$ (Bertrand et al., 2008a; Bertrand et al., 2008b).

b) Fe-rich clay to fine silt laminae (FeLs). The FeLs have a yellowish appearance in thin section (Suppl. Fig. 4) and are present as single thin laminae or thicker zones with yellowish clays crossing varve boundaries. They are characterized by very high $\mathrm{Fe} / \mathrm{Si}$ ratios $(\mathrm{Fe} / \mathrm{Si}>2.50)$ -corresponding to a mafic composition-, but MS values do not exceed the background values (Fig. 4). Occasionally, these laminae occur immediately above tephra-fall deposits and, based on varve chronology, young FeLs can be unambiguously linked to historical eruptions of Villarrica Volcano (e.g., 1980 and 1984; see further). Hence, we interpret these laminae as a product of a volcanic eruption, representing fluvially transported very fine ash, or cryptotephra, which was originally deposited in the catchment area by an eruption. This implies that an eruption does not necessarily have to cause tephra fall on the lake surface to be represented in the sedimentary record. Since precipitation is significantly higher during the winter months, remobilization and initial redeposition of the cryptotephra can be delayed by several months to a year. Once the cryptotephra reaches the lake, transport across the lake basin can occur by over- or interflows, depending on lake stratification, in a similar way as the finest particles of the lahar deposits (see further).

c) Detrital fining-upwards EDs (lahar deposits). The detrital fining-upwards EDs are brown layers or laminae with a light beige or light gray top component. Both the basal and the top component show high MS values. The basal component is normally graded (coarse or fine sand to medium silt) and characterized by very high $\mathrm{Fe} / \mathrm{Si}$ ratios $(\mathrm{Fe} / \mathrm{Si}>2.50)$. Thin-section analysis shows that it is exclusively composed of crystals and volcanic glass, without any diatom frustules (Suppl. Fig. 4). Occasional parallel- or cross-laminated sediment structures occur, consisting of alternations between coarser and finer sands (i.e. coarse ash; Fig. 3). The grain size of the top component ranges from clay to fine silt (mode: 3-20 $\mu$ m; i.e. fine ash) and is characterized by very high $\mathrm{Al} / \mathrm{Si}$ ratios and high $\mathrm{Fe} / \mathrm{Si}$ ratios $(0.13<\mathrm{Al} / \mathrm{Si}<0.20, \mathrm{Fe} / \mathrm{Si}>$ 2.00; Fig. 4). Tops with a more grayish color (Figs. 2 and 3) have the highest Fe/Si ratios. Thinsection analysis shows that these top components consist of brownish amorphous detritus, with diatom frustules virtually absent. The exclusively mineral and glass composition of the detrital fining-upwards EDs is indicative of a volcanic origin. However, both the depth-dependent thickness of the deposits and the occasional cross-lamination argue against an interpretation of tephra-fall deposits.

The detrital fining-upwards EDs are thickest and coarsest in cores in the deepest parts and closest to historical lahar inflows into lakes Villarrica and Calafquén (Urrutia de Hazbún and Lanza Lazcano, 1993; González-Ferrán, 1994; Petit-Breuilh, 2004; Naranjo and Moreno, 2004; Keller et al., 2008; Fig. 2 and 3). The brown coarse basal parts are well developed in the deepest parts and close to historical lahar inflows, while the light-colored top components drape the entire lake floor, but are thinner and less obvious in shallower areas (Figs. 2 and 3). The formation of these deposits - once the lahar reaches the lake shore- can be explained by an underflow with suspension cloud combined with an inter- or overflow (Sturm and Matter, 1978; 
Fig. 5). An underflow -transporting medium silts to boulders- will result in a deposit mainly in the proximal (including the boulders on a deltaic fan) and deep parts. During this transport, a portion of the silt particles will go into suspension and form a suspension cloud above the underflow. Particles transported in this suspension cloud will also be deposited further away from the lahar inflow and at shallower depths. The finest fraction will be transported by an overflow -when the lake is not stratified in winter- or by an interflow developing at the thermocline. These over- or interflows will spread the fine sediments over the entire lake, however still in higher amounts in the proximal and deep areas (Fig. 5). Deposits with a light gray top (and higher Fe/Al values), in contrast to light beige, are considered to contain a higher amount of fresh ash compared to reworked terrestrial clays and soils.

Volland et al. (2007) already suggested that lahars might have a major impact on the sedimentary infill of Lake Calafquén, but concluded that the characteristics of lahar deposits on seismic profiles would be very similar to those of floods. Except for the deltaic fans close to the lahar inflows, which are probably mostly built up by lahars, the lahar deposits are too thin to be detected by seismic profiling. The flood deposits encountered in Lake Puyehue by Chapron et al. (2007) -and linked to landslide dams caused by the 1960 earthquake- are quite similar to the lahar deposits we find this study (i.e. brown color, fining upwards with beige finesilt cap). However, the former are located at only $2.5 \mathrm{~km}$ from the main river inlet, and lack the coarse grained base of the lahar deposits at more distal locations in lakes Calafquén and Villarrica. This coarser nature of the latter is due to the potential of lahars to carry much coarser material into the lake (boulders of several cubic meters; Vallance, 2000; Naranjo and Moreno, 2004; Castruccio et al., 2010). Moreover, the perennially high amount of winter precipitation and low interannual rainfall variability (Suppl. Fig. 1) show that exceptional flooding events did not occur in the last 50 years. Hence, flood deposits such as the ones in Lake Puyehue in 1960 are only expected to occur when other natural events (e.g., earthquakes, volcanic eruptions) provide easily erodible material in the catchment. Also, historical lahar inflows are not necessarily located in the same areas as the main river inflows (Figs. 1, 2 and 3). For our detrital fining-upwards EDs, a lahar origin is considered most likely because flood deposits would all be coarser and thicker towards the Trancura or Llancahue River deltas in lakes Villarrica and Calafquén, respectively. Finally, the chronological link of these deposits with historical lahars -and not with precipitation- (e.g., 1964 and 1971; see further; Figs. 6 and 7) confirms the interpretation as a lahar deposit.

\subsection{Event-deposit chronology}

The origin and formation process of each type of ED is strongly supported by the tight correlation with recent seismic and volcanic events. The combined sedimentary records of the lakes contain a robust and virtually complete event-deposit chronostratigraphy of major earthquakes, volcanic eruptions with a Volcanic Explosivity Index (VEI) $\geq 2$ (i.e. explosive eruptions, Newhall and Self, 1982) and eruption-induced lahars for the last c. 500 years. Both lakes contain the four types of event deposits. In this section, we present a new event deposit chronology for each of these four depositional types.

\section{i) Lacustrine turbidites}

The four strongest earthquakes that ruptured the Valdivia segment in historical times occurred in 1575, 1737, 1837 and 1960; and are all represented by lacustrine turbidites in the 
lakes' sedimentary sequences (LT-4, LT-3, LT-2 and LT-1, respectively). Additionally, a fifth lacustrine turbidite (LT-0) occurs at the top of some cores taken in the 2010-11 field season (Figs. 2 and 3). This lacustrine turbidite was not found in cores taken at the same locations during previous field seasons. Therefore, we attribute LT-0 to the 2010 Maule earthquake. This observation is consistent with a seismic origin of the lacustrine turbidites observed in the studied lakes.

The youngest buried lacustrine turbidite LT-1 has a varve age of 1960 in both lakes and occurs just below the below the ${ }^{137}$ Cs-peak (Suppl. Figs. 5 and 6; Suppl. Table 2). Hence, this turbidite is attributed to the Great Chilean earthquake of May 22, 1960. The European Macroseismic Intensity of the 1960 earthquake in the study area has been estimated at VII to VIII (Lazo, 2008), which is equal to or higher than the minimum intensity necessary to induce subaquatic landslides and lacustrine turbidites in Alpine lakes (Monecke et al., 2004; Strasser et al., 2011). Most cores contain another lacustrine turbidite (LT-4), which has a varve age of 1583 in Lake Villarrica and 1579 in Lake Calafquén (Figs. 6 and 7; Suppl. Figs. 5 and 6; Suppl. Table 2). We attribute LT-4 to the 1575 earthquake, which had similar effects as the 1960 earthquake (Lomnitz, 1970; Lomnitz, 2004; Cisternas et al., 2005). Between these two lacustrine turbidites, two more turbidites occur in some cores of each lake (i.e. LT-3 and LT2). With varve ages of 1739 and 1830 in Villarrica, and 1732 and 1839 in Calafquén (Figs. 6 and 7; Suppl. Figs. 5 and 6; Suppl. Table 2), we attribute these to the major subduction earthquakes that occurred in 1737 and 1837, respectively, along the Valdivia segment (Lomnitz, 2004).

In addition to these five main lacustrine turbidites that occur in both lakes, some local turbidites are also present that are inferred to be the product of small subaquatic landslides (Figs. 2 and 3). These were probably generated by small, local earthquakes or by large, more distant earthquakes.

\section{ii) Volcanic-eruption-induced EDs}

Apart from one lahar pathway on the western slope of Villarrica Volcano, the catchment areas of lakes Villarrica and Calafquén cover all the slopes of the volcano (Fig. 1). This nearcomplete coverage of the volcano ensures that all events that altered the volcano's surface to a certain degree are likely to be detected somehow in at least one of the lakes.

In this section, we attribute the three types of volcanic eruption-induced EDs to historically known eruptions using age-depth models with lacustrine turbidites as correlation tie-points. From the 20th century onwards, historical reports are more or less complete and reliable, and we were able to calibrate the sedimentary record by comparing historical reports to the record of volcanic EDs in lakes Villarrica and Calafquén. For each of the 17 VEI $\geq 2$ eruptions of Villarrica Volcano described in 20th century historical records, as well as for one VEI 1 eruption (1915-1918), an ED was identified in lakes Calafquén and/or Villarrica, under the form of tephra-fall, FeLs and/or lahar deposits. The robust correlation for the 20th century record allows the reconstruction of a volcanic eruptive event stratigraphy for Villarrica Volcano for the last c. 500 years (Suppl. Table 2). Volcanic-eruption induced EDs were correlated between lakes Villarrica and Calafquén, and matched to historical eruptions, resulting in a calibrated varve age or calendar age. Where no historical match exists, a calendar age was calculated for the ED from the varve age by linear interpolation between calendar ages of the previous and next ED linked to a historical earthquake or eruption. Inter-lake correlation of 
some of the EDs revealed local offsets (of the order of a few years) in the varve-based age model, especially in Lake Villarrica. These offsets are due to parts in the core in which varves are unclear because of higher amounts of terrestrial input, masking the diatom bloom bed.

a) Tephra fall-out layers and b) FeLs. Several thin FeLs occur in the 20th century sediments from lakes Calafquén and Villarrica. Only one of these laminae (i.e. 1955 in Lake Villarrica) could not be linked to a historically described eruption of Villarrica Volcano. The two youngest FeLs occur in varve years 1982 and 1984 and are correlated to the two VEI 2 eruptions of 1980 and 1984, respectively (Figs. 4 and 7). Above these events, the Fe/Si ratio of the background sediment gradually decreases (Fig. 4). This is interpreted as the result of fine ash deposited in the catchment area, gradually getting washed into rivers and the lakes for months to years after the eruption.

Numerous FeLs observed in Lake Calafquén at varve years 1904, 1907, 1910, 1918, 1924 and 1929 can be correlated to historical Villarrica eruptions in 1904, 1906, 1909, 1915 1918, 1922 and 1927, respectively (Fig. 7, Suppl. Table 2). All have a VEI of 2, with the exception of the VEI 1 1915-1918 eruption. Lake Villarrica contains FeLs in varve years 1908, 1935, 1955 and 1994, the latter three of which can be correlated to the eruptions of 1933, 195556 and 1991, respectively (Fig. 6; Suppl. Table 2). In the entire studied time period, 73 FeLs were detected in lakes Calafquén and/or Villarrica and because of the strong correlation with historical eruptions in the 20th century record, we also attribute older FeLs to VEI $\geq 2$ eruptions of Villarrica Volcano.

Since 1400, 10 Villarrica eruptions directly deposited tephra fall in lakes Villarrica and/or Calafquén (Suppl. Table 2). This number is much lower than the 73 FeLs in our records. This can be explained by the predominant westerly wind directions in this region (Kalnay et al., 1996), blowing ash clouds towards the east, away from the lakes.

The glass major element geochemistry of the tephra-fall deposits attributed to Villarrica Volcano (i.e. CT-2, CT-3, CT-5 and CT-8; Figs. 3 and 7) reveals a mafic-intermediate composition with intermediate $\mathrm{K}_{2} \mathrm{O}$ content, which corresponds well with previously published whole-rock data of deposits from Villarrica Volcano (Hickey-Vargas et al., 1989; Costantini et al., 2011; Lohmar et al., 2012; Fig. 8, Suppl. Table 3). Also CT-6 follows this trend, however, a significant amount of $\mathrm{Cr}$ in the Ti-magnetites differentiate this tephra from the other tephras and might indicate a different subduction-proximal source, such as Mocho-Choshuenco Volcano. The phenocryst assemblage of the Villarrica tephras is characterized by plagioclase, olivine, Ti-magnetite and clinopyroxene (clinoenstatite / pigeonite), in decreasing order of abundance.

Not all tephra-fall layers can be attributed to Villarrica Volcano. Tephra-fall deposits CT-9 and VT-2 have distinct felsic glass geochemistry (Fig. 8; Suppl. Table 3) with significant higher $\mathrm{K}_{2} \mathrm{O}$ contents than the Villarrica tephra-fall deposits and similar to the whole-rock data for dacitic rocks from the historically active Quetrupillán Volcano (Hickey-Vargas et al., 1989; Fig. 8). Moreover, these tephra-fall deposits are covered by a lahar deposit in both lakes Calafquén and Villarrica, confirming the link with Quetrupillán Volcano, which is part of both of the lakes' catchments.

Tephra CT-1 occurs in varve year 1956 (Fig. 7). The mineralogy of this tephra shows signs of contamination by a granite-like basement (occurrence of free quartz, biotite, zircon, clinopyroxene (augite) and titanite). This is not found in the tephra-fall deposits linked to 
Villarrica, so we infer that these free xenocrysts are not part of the background sediment, but were indeed erupted and deposited together with the juvenile mafic-intermediate tephra. The high number of microlites in the glass complicates geochemical characterization, but the geochemical signature does correspond to that of very recent (i.e. with only some grassy soil developed) coarse ash-fall deposits in the proximity of the Carrán-Los Venados Volcanic Complex. Because of the geochemical and age correspondance, we attribute this slightlyhigher- $\mathrm{K}_{2} \mathrm{O}$ tephra-fall (Fig. 8) deposit to the 1955 VEI 4 eruption of the Carrán-Los Venados Volcanic Complex (Petit-Breuilh, 2004; Siebert et al., 2010). During this eruption southerly winds caused fine ashfall as far north as Santiago (Stern et al., 2007). A single FeL in the more remote Lake Villarrica in varve year 1955 (Fig. 6) was linked to the same eruption.

The lack of microlite-free glass in tephra CT-4 inhibited characterization of glass geochemistry. Just like CT-1, there are signs for granitic contamination, in this case by the occurrence of free quartz, biotite, alkali feldspar, augite and titanite. Based on mineralogy and the high amount of microlites, this tephra-fall deposit is also tentatively attributed to the CarránLos Venados Volcanic Complex.

VT-1 and CT-7 have a distinct, rather mafic, glass geochemistry (Fig. 8, Suppl. Table 3 ), which corresponds very well to the geochemical signature of scoria fall deposits from the c. 400 year old eruption of Achen Niyeu of the Huanquihue Group. The varve years of these deposits are 1594 in Lake Villarrica and 1598 in Lake Calafquén. After correction of the varve years -aided by the correlation of LT-4 to the 1575 earthquake- the tephra-fall deposit was assigned to the year 1591. Because of the distinct age similarity and the distinct geochemical signature, we attribute these tephra-fall deposits to this most recent eruption of the Huanquihue Group. The inter-lake correlation of several of these tephra-fall deposits and the limited offsets in varve age between these deposits support the varve-based age models for both lakes.

c) Detrital fining-upwards EDs (lahar deposits). All nine historically documented lahar events at Villarrica Volcano in the 20th century are represented by detrital fining-upwards EDs in lakes Calafquén and/or Villarrica. The five youngest lahar events, in 1948, 1949, 1963, 1964 and 1971, were reported to have reached both lakes Calafquén and Villarrica (Fig. 9, Suppl. Table 2). All of these events are indeed represented by lahar deposits in both lakes (Figs. 6 and 7). For the four oldest 20th century events, in 1904, 1908, 1909 and 1920, lahars were only reported in the Lake Villarrica catchment, and only the 1908 lahars reached the lake shore (Fig. 9, Suppl. Table 2). Indeed, these lahars are only represented in Lake Villarrica (Fig. 6). Lakes Calafquén and Villarrica each contain one thin $(<1 \mathrm{~mm})$ lahar deposit that does not correspond to reported lahars, but which can be linked to the historical eruptions of 1938 and 1991, respectively (Figs. 6 and 7; Suppl. Table 2). They are possibly the imprint of small lahars in the catchment.

The variations in thickness and maximum grain size of each lahar deposit in the different sediment cores correlate well with both the lake water depth and the distance to the location where the lahars entered the lake according to the historical records. Furthermore, the extent of the reported lahars correlates well with the characteristics of the lahar deposits in both lakes. When lahars were reported in channels draining towards a certain lake, but without reaching the lake shore, the lahar deposit consists of a clay to silt lamina without a coarser silt base, never exceeding a total thickness of $1 \mathrm{~cm}$. Cores in the shallowest parts of the lakes only comprise a faint clay/silt lamina or no visible deposit. Lahars that were reported to have entered the lake 
are almost always represented by deposits that are locally thicker than $1 \mathrm{~cm}$ and that have coarse silt to sand bases. Major lahars (e.g., 1948 and 1971) are always represented by thick deposits in the deepest parts of the lake, locally thicker than $5 \mathrm{~cm}$. Close to the shore, where core retrieval was not possible, lahar deposits are probably much thicker. The thick and coarse deposits of the 1964 lahars in the eastern part of Lake Calafquén correlate well with the large reported lahars that destroyed the village of Coñaripe at the eastern tip of the lake (Figs. 1 and 9). In shallower coring locations, the reported extent of the lahars correlates with the thickness and type of the deposit. That is, lahars not reaching the lake shore, small lahars entering the lake and large lahars entering the lake are represented by no, faint or clear silt to clay laminae, respectively (Fig. 9).

Almost half of the volcanic events related to Villarrica Volcano produced a lahar deposit in lakes Villarrica and/or Calafquén, but Lake Villarrica contains more lahar deposits than Lake Calafquén. This discrepancy can be explained by the larger number of lahar pathways in Lake Villarrica's catchment. Most lahar deposits in Lake Villarrica are smaller or comparable in size to the 1908 lahars, which reached the lake shore. Only the 1893 and 1822 lahars seem to have been of a size similar to that of the large 1948 or 1971 lahars (Figs. 4 and 7). In Lake Calafquén, several similar-sized lahar deposits occur, e.g., 1617 and 1688 lahars. In 1822, just like in 194849 or 1963-64, two lahar events occurred in a short period of time and are interpreted to belong to the same eruptive event (Figs. 3 and 7). Since 1400, at least 22 events occurred during which lahars reached the shores of lakes Villarrica and/or Calafquén; hence, on average almost 4 potentially destructive lahar events per 100 years. The cluster of lahar deposits between 1470 and 1530 and the lack of such deposits in the previous $~ 300$ years (determined by extrapolation in other cores; Figs. 3 and 10) are in strong contrast with the constant activity of the volcano. The formation of lahars during an eruption depends on many factors: i) the type of eruption, ii) the morphology of the upper part of the volcano, iii) the availability of erodible material on the lower slopes of the volcano, iv) the availability and state of the snow cover, and v) the amount of vegetation on the slopes (Vallance, 2000). The last two variables are climate-related and are important in lahar formation and hence, might be important for this clustering. Based on the historical data, however, we believe that all lahar deposits are linked to an eruption of Villarrica Volcano. Rather than rainfall or gradual spring snowmelt, which occur yearly, it is the sudden snowmelt (just before and) during an eruption, which is the determining factor for lahar formation in this region. Hence, climatic changes can enhance or reduce the chance for a lahar to form during an eruption, but not produce the lahar on their own.

\subsection{The eruptive record of Villarrica Volcano}

Due to the nearly total coverage of Villarrica Volcano by the combined catchments of lakes Villarrica and Calafquén, we have obtained a complete VEI $\geq 2$ eruptive record for this volcano. The correlation between the number of reported eruptions and our eruption record is closely linked with the development of the town of Villarrica. Essentially, the number of reported eruptions is higher during periods of increased population in the region. Before 1860, the number of historically reported eruptions is much smaller than the number of actual volcanic EDs. During the last 150 years the reports gradually became more detailed and the assignment of an accurate VEI has improved. The number of reported small, non-explosive eruptions (VEI 
1) is higher in the last century and has significantly increased since the start of the Villarrica Volcano Visual Observation Project (POVI; http://www.povi.cl) in 1996 (Fig. 10).

Overall, our record comprises 112 EDs of which 47 could be matched with historically known eruptions. Half of the historically known eruptions were large enough to be detected in both lakes, while three quarters of the newly described eruptions were smaller and found only in one of the lakes (Suppl. Table 2). Between 1523 and 2011, the period for which data for both lakes Calafquén and Villarrica are available, our eruption record contains 88 EDs, with on average $1 \mathrm{VEI} \geq 2$ eruption every 5.32 years (or 3.95 eruptions/21 years; Figs. 10 and 11B). The period between 1870 and 1910 is marked by increased volcanic activity (Figs. 10 and 11A). During this period a VEI $\geq 2$ eruption occurred once every 2.68 years.

\subsection{Probability of a future eruption}

The new VEI $\geq 2$ eruption time series of Villarrica Volcano -with 88 eruptions since 1523- was statistically examined to provide a probability estimate for the occurrence of future eruptions. Dzierma and Wehrmann (2010) applied statistical techniques on the time series of historical records of Villarrica and Llaima eruptions. However, Fig. 10 highlights the comparative incompleteness of the pre- 1860 historical records used by Dzierma and Wehrmann (2010). Here we repeat the same statistical analyses based on the new (and more complete, i.e. 45 additional VEI $\geq 2$ eruptions), combined Villarrica-Calafquén lacustrine eruption record from 1523 to 1991, the year of the last VEI 2 eruption (Fig. 10). Since we do not know the exact VEI for each eruption, we treat every detected eruption equally during this analysis, i.e. an eruption which only deposited an FeL is given the same weight as an eruption that leaves a lahar deposit, tephra-fall layer and FeL. We also refer to Dzierma and Wehrmann (2010) for more detailed information on the analysis technique.

We first tested if the eruptions in the time series occur independently from one another, by calculating the correlation coefficient of all successive repose times. The resulting correlation coefficient $\mathrm{R}=0.073$ is even lower than the $\mathrm{R}=0.16$ of Dzierma and Wehrmann (2010) and is therefore consistent with the hypothesis of no correlation, meaning that memory effects between successive eruptions are lacking and the time series can be modeled as a Poisson process (three distributions will be modeled).

To test whether the repose time series is stationary, with one distribution explaining the entire examined time interval, a moving-average test was implemented. The average of each five successive repose times was calculated. The 5-point repose time averages for the last 500 years fall within the $95 \%$ confidence interval, but approximate both upper and lower boundaries closely (Fig. 11D). The repose time series can be regarded as stationary (i.e. a stable eruption regime through time), although the occurrence of clusters cannot be ruled out. Both results are in contrast with the results of Dzierma and Whermann (2010), who could not confirm stationarity for the early eruption record. They attributed this result to a change in eruption frequency or incompleteness of the early eruption record. Based on our new data, we can reject the first option and confirm the latter. Moreover, some large repose times in their early record widened the confidence interval, leading to the flawed conclusion of stationarity in the most recent period. A critical review of the completeness of historical records by e.g. comparison with the local or regional history -as we did in Fig. 10- is highly recommended for other study areas as well. 
Three types of distributions were fitted to the cumulative number of repose times: a Weibull (favoring stationarity, i.e. continuous rising of the probability of an eruption in a certain year after the last eruption), a log-logistic (favoring some clustering, i.e. initial fast rising probability, followed by a decrease) and an exponential (intermediate, i.e. a constant identical probability) distribution (Fig. 11B and C). The histogram of the repose times is best fitted with a Weibull distribution (based on highest $\mathrm{R}^{2}$ and best Kolmogorov-Smirnov test results; Fig. $11 \mathrm{C}$ ), which for the short repose times ( $<10$ years) is visible in Fig. 11B. However, for longer repose times (>10 years), the log-logistic and exponential distributions provide more reliable estimates (Fig. 11B and C).

At the time of writing, the last VEI $\geq 2$ eruption happened 22 years ago in 1991, an uncommonly long repose in the past 600 years. The probability of a 22-year period without VEI $\geq 2$ eruptions is $\leq 1.7 \%$ : the Weibull model reached a $99.9 \%(=100 \%-0.1 \%)$ probability, the log-logistic and exponential models resulted in probabilities of $98.3 \%(=100 \%-1.7 \%)$ and $99.2 \%$ (= $100 \%-0.8 \%$ ), respectively (Fig. 12). In the Weibull model, the probability of a new $\mathrm{VEI} \geq 2$ eruption in a certain year or period -given that no VEI $\geq 2$ eruption has occurred in the meantime - is at this moment continuously rising, for the exponential model this probability stays equal, while for the log-logistic model the probability of a new eruption decreases with time (Fig. 12B and C). The better model for longer repose times of the latter two distributions suggests that there might be some clustering for $\mathrm{VEI} \geq 2$ eruptions. This raises the question as to whether the high number of reported VEI 1 eruptions and continuous degassing from an active lava lake during the last two decades (Witter et al., 2004) is only due to more continuous observations (we do not have information on the existence of a lava lake and thus an open conduit system before this period) or also reflects real changes in eruptive mode. In the latter case, this activity may decrease the probability of a VEI $\geq 2$ eruption, favoring the log-logistic and exponential models. Another explanation for the high probabilities is an overestimation of the amount of eruptions based on the EDs due to deposits that are a result of floods or eruptions of more distant volcanoes. However, based on the available historical (1 out of 18 deposits could not be linked to an eruption in the $20^{\text {th }}$ century) and meteorological (no years with extremely enhanced rainfall) data, such contribution is expected to be minor.

To summarize, our new lacustrine-based eruption time series suggests that a VEI $\geq 2$ eruption from Villarrica in the near future is likely. This study is an addition to previous studies on volcanic hazards in the Villarrica region such as the volcanic hazard map by Moreno (2000) and the overview presented by Lara (2004). We provide time series that can be used to better assess the hazards in different areas of the volcano already depicted by Moreno (2000). In particular, improved hazard assessments for lahars on the many historical lahar pathways should be a priority because of their flat morphology and proximity to beaches which are usually preferred for building (tourist) accommodation. We note, however, that lahars occur on a more irregular basis especially in the Lake Calafquén catchment, and a possible climatic control on lahar formation must -in contrast to eruptions in general- be further examined to be able to provide probability estimates for lahar occurrence.

\section{CONCLUSIONS}


1) Using high-resolution multi-proxy analyses of sediment cores in lakes Villarrica and Calafquén, we have constructed a new, more detailed and reliable 500-year-long eruption record for Villarrica Volcano.

2) A combination of $\mu \mathrm{XRF}$ scanning combined with standard sedimentological techniques allowed the systematic detection of very thin event deposits (EDs) in an objective and efficient manner down to a thickness of $100 \mu \mathrm{m}$. We detected and classified four types of EDs and divided them into two groups, lacustrine turbidites and volcanic eruption-induced EDs.

(i) Lacustrine turbidites are homogenous deposits that fine upwards and have a composition similar to that of the background sediment. They can all be attributed to known megathrust earthquakes

(ii) Volcanic eruption-induced EDs were subdivided into three sub-types: a) tephra-fall layers: characterized by draping coarse ash with very high $\mathrm{Fe} / \mathrm{Si}$ and high $\mathrm{Al} / \mathrm{Si}$ ratios; b) $\mathrm{Fe}$ rich clay to fine silt laminae (FeLs): clays and fine silts with a high $\mathrm{Fe} / \mathrm{Si}$ ratio, that record fluvial erosion and transport of cryptotephra into the lake; c) lahar deposits: fining upwards EDs with coarse basal deposits close to the inflow (high $\mathrm{Fe} / \mathrm{Si}$ ) and a fine silt to clay with the same composition as the detrital component of the background sediment (high $\mathrm{Al} / \mathrm{Si}$ and $\mathrm{Fe} / \mathrm{Si}$ )

3) Our lacustrine dataset significantly improves the eruption record of Villarrica Volcano, with a total $88 \mathrm{VEI} \geq 2$ eruptions identified between 1523 and 1991. Between $\sim 1350$ and 1523, 24 more VEI $\geq 2$ eruptions were identified, but that part of the record is incomplete since it is only based on Lake Calafquén. Villarrica Volcano has experienced nearly constant eruptive activity during the past 600 years with an average and median since 1523 of one eruption (VEI $\geq 2$ ) every 5.32 and 4.5 years, respectively. The last VEI $\geq 2$ eruption occurred in 1991. The probability of a 22-year repose period (anno 2013) is $\leq 1.7 \%$. Based on the last 600 years, we conclude that there is a high probability of a VEI $\geq 2$ eruption in the near future. However, the possibility of cluster occurrence and hence, a temporarily decreasing activity, cannot be excluded.

4) Probability estimates should be used to improve existing hazard assessments for Villarrica Volcano region.

5) Geochemical and mineralogical analysis allowed to link some of the tephra-fall deposits to the Carrán-Los Venados Volcanic Complex, Quetrupillán Volcano and the Huanquihue Group volcanoes.

\section{ACKNOWLEDGEMENTS}

This research was funded mainly by the Research Foundation Flanders (FWOVlaanderen) and by the Special Research Fund of Ghent University (BOF). We thank the GSA Limnogeology Division for the Kerry Kelts award and IAS for the postgraduate student grant, both used in the last field season. M. Vincx is acknowledged for the use of the Malvern Mastersizer 2000. We thank Ph. De Smedt for sharing the Bartington MSE2 point sensor. Special thanks to J. Yurcika for the help during thin-section preparation and to P. Van den haute for putting the thin-section lab at our disposal. We are grateful to V. Cnudde for use of the petrographic microscope and J. Mortier for help with the use of the SEM. We thank N. Fagel for performing the XRD measurements. We are grateful to R. Brümmer for help with logistics etc. in Valdivia. Finally we thank A. Peña for the invaluable assistance on the field. We acknowledge the constructive reviews by W. Scott and three anonymous reviewers. K. Fontijn 
is supported by NERC grant NE/I013210/1. J. Moernaut acknowledges the support of the Research Foundation Flanders (FWO-Vlaanderen) and the Swiss National Science Foundation (grant 133481). M. Van Daele acknowledges the support of the Research Foundation Flanders (FWO-Vlaanderen).

\section{REFERENCES CITED}

Angermann, D., Klotz, J., and Reigber, C., 1999, Space-geodetic estimation of the nazca-south america euler vector: Earth and Planetary Science Letters, v. 171, p. 329-334.

Arnaud, F., Magand, O., Chapron, E., Bertrand, S., Boes, X., Charlet, F., and Melieres, M., 2006, Radionuclide dating ((210) $\mathrm{Pb},(137) \mathrm{Cs},(241) \mathrm{Am})$ of recent lake sediments in a highly active geodynamic setting (Lakes Puyehue and Icalma-Chilean Lake District): Science of the Total Environment, v. 366, p. 837-850.

Beck, C., 2009, "Late Quaternary lacustrine paleo-seismic archives in north-western Alps: Examples of earthquake-origin assessment of sedimentary disturbances": Earth-Science Reviews, v. 96, p. 327-344.

Bertrand, S., and Fagel, N., 2008, Nature, origin, transport and deposition of andosol parent material in south-central Chile (36-42 ${ }^{\circ}$ S): Catena, v. 73, p. 10-22.

Bertrand, S., Charlet, F., Chapron, E., Fagel, N., and De Batist, M., 2008a, Reconstruction of the Holocene seismotectonic activity of the Southern Andes from seismites recorded in Lago Icalma, Chile, $39^{\circ} \mathrm{S}$ : Palaeogeography, Palaeoclimatology, Palaeoecology, v. 259, p. 301-322.

Bertrand, S., Castiaux, J., and Juvigné, E., 2008b, Tephrostratigraphy of the Late Glacial and Holocene sediments of Puyehue Lake (Southern Volcanic Zone, Chile $40^{\circ} \mathrm{S}$ : Quaternary Research, v. 70, p. 343-357.

Boës, X., and Fagel, N., 2008, Relationship between southern Chilean varved lake sediments, precipitation and ENSO for the last 600 years: Journal of Paleolimnology, v. 39, p. 237-252.

Campos, H., Steffen, W., Román, C., Zúñiga, L., and Agüero, G., 1983, Limnological studies in Lake Villarrica: Morphometric, physical, chemical, planktonical factors and primary productivity: Archiv für Hydrobiologie Supplement, v. 65, p. 371-406.

Campos, H., Steffen, W., Agüero, G., Parra, O., and Zúñiga, L., 1989, Estudios limnologicos en el Lago Puyehue (Chile): Morfometria, factores fisicos y quimicos, plancton y productividad ad primaria: Medio Ambiente, v. 10, p. 36-53.

Carn, S.A., Pallister, J.S., Lara, L., Ewert, J.W., Watt, S., Prata, A.J., Thomas, R.J., and Villarosa, G., 2009, The unexpected awakening of Chaitén Volcano, Chile: EOS, Transactions, American Geophysical union, v. 90, p. 205.

Castruccio, A., Clavero, J., and Rivera, A., 2010, Comparative study of lahars generated by the 1961 and 1971 eruptions of Calbuco and Villarrica volcanoes, Southern Andes of Chile: Journal of Volcanology and Geothermal Research, v. 190, p. 297-311.

Cembrano, J., and Lara, L. 2009, The link between volcanism and tectonics in the southern volcanic zone of the Chilean Andes: A review: Tectonophysics, v. 471, no. 1-2, p. 96113. 
Cembrano, J., Schermer, E., Lavenu, A., and Sanhueza, A., 2000, Contrasting nature of deformation along an intra-arc shear zone, the Liquine-Ofqui fault zone, southern Chilean Andes: Tectonophysics, v. 319, p. 129-149.

Chapron, E., Ariztegui, D., Mulsow, S., Villarosa, G., Pino, M., Outes, V., Juvignié, E., and Crivelli, E., 2006, Impact of the 1960 major subduction earthquake in Northern Patagonia (Chile, Argentina): Quaternary International, v. 158, p. 58-71.

Chapron, E., Juvigné, E., Mulsow, S., Ariztegui, D., Magand, O., Bertrand, S., Pino, M., and Chapron, O., 2007, Recent clastic sedimentation processes in Lake Puyehue (Chilean Lake District, $40.5^{\circ} \mathrm{S}$ ): Sedimentary Geology, v. 201, no. 3-4, p. 365-385.

Cifuentes, I.L., 1989, The 1960 Chilean Earthquakes: Journal of Geophysical ResearchSolid Earth and Planets, v. 94, p. 665-680.

Cisternas, M., Atwater, B.F., Torrejon, F., Sawai, Y., Machuca, G., Lagos, M., Eipert, A., Youlton, C., Salgado, I., Kamataki, T., Shishikura, M., Rajendran, C.P., Malik, J.K., Rizal, Y., and Husni, M., 2005, Predecessors of the giant 1960 Chile earthquake: Nature, v. 437, p. 404-407.

Costantini, L., Pioli, L., Bonadonna, C., Clavero, J., and Longchamp, C., 2011, A Late Holocene explosive mafic eruption of Villarrica volcano, Southern Andes: The Chaimilla deposit: Journal of Volcanology and Geothermal Research, v. 200, no. 3-4, p. 143-158.

DeMets, C., Gordon, R.G., Argus, D.F., and Stein, S., 1994, Effect of recent revisions to the geomagnetic reversal time scale on estimate of current plate motions: Geophysical Research Letters, v. 21, p. 2191-2194.

Dzierma, Y., and Wehrmann, H., 2010, Eruption time series statistically examined: Probablilities of future eruptions at Villarrica and Llaima Volcanoes, Southern Volcanice Zone, Chile: Journal of Volcanology and Geothermal Research, v. 193, p. 82-92.

Geller, W., 1992, The temperature stratification and related characteristics of Chilean lakes in midsummer: Aquatic Sciences, v. 54, no. 1, p. 37-57.

Gill, J.B., 1981, Orogenic Andesites and Plate Tectonics: Springer Verlag, Berlin Heidelberg, New York, 385 p.

González-Ferrán, O., 1994, Volcanes De Chile: Instituto geografico militar, Santiago, $640 \mathrm{p}$.

Heusser, C., 2003, Ice age Southern Andes - A chronicle of palaeoecological events: Elsevier, Amsterdam, 230 p.

Hickey-Vargas, R., Roa, H. M., Escobar, L. L., and Frey, F. A., 1989, Geochemical variations in Andean basaltic and silicic lavas from the Villarrica-Lanin volcanic chain $\left(39.5^{\circ}\right.$ S): an evaluation of source heterogeneity, fractional crystallization and crustal assimilation: Contributions to Mineralogy and Petrology, v. 103, p. 361-386.

Kalnay, E., Kanamitsu, M., Kistler, R., Collins, W., Deaven, D., Gandin, L., Iredell, M., Saha, S., White, G., Woollen, J., Zhu, Y., Leetmaa, A., Reynolds, R., Chelliah, M., Ebisuzaki, W., Higgins, W., Janowiak, J., Mo, K.C., Ropelewski, C., Wang, J., Jenne, R., and Joseph, D., 1996, The NCEP/NCAR 40-Year Reanalysis Project: Bulletin of the American Meteorological Society, v. 77, p. 437-471.

Katsuta, N., Takano, M., Kawakami, S.I., Togami, S., Fukusawa, H., Kumazawa, M., and Yasuda, Y., 2007, Advanced Micro-XRF method to separate sedimentary rhythms and 
event layers in sediments: Its application to lacustrine sediment from Lake Suigetsu, Japan: Journal of Paleolimnology, v. 37, p. 259-271.

Keller, W., Bacher, H., Marfull, V., and Koller, A., 2008, Villarrica Volcano Visual Observation Project (POVI), Historia Eruptiva: http://www.povi.cl/history.html (accessed September 2011).

Kylander, M.E., Lind, E.M., Wastegård, S., and Löwemark, L., 2011, Recommendations for using XRF core scanning as a tool in tephrochronology: The Holocene, v. 22, p. 371-375.

Lara, L.E., 2004, Overview of Villarrica Volcano, in L.E. Lara and J. Clavero (Editors), Villarrica Volcano $\left(39.5^{\circ} \mathrm{S}\right)$, Southern Andes, Chile: Servicio Nacional de Geología y Minería, p. 5-12.

Lara, L.E., 2009, The 2008 eruption of the Chaiten Volcano, Chile: a preliminary report: Andean Geology, v. 36, p. 125-129.

Lazo, R.G., 2008, Estudio de los daños de los terremotos del 21 y 22 de mayo de 1960: Universidad de Chile, Santiago, 427 p.

Lohmar, S., Parada, M., Gutierrez, F., Robin, C., and Gerbe, M. C., 2012, Mineralogical and numerical approaches to establish the pre-eruptive conditions of the mafic Lican Ignimbrite, Villarrica Volcano (Chilean Southern Andes): Journal of Volcanology and Geothermal Research, v. 235, p. 55-69.

Lomnitz, C., 1970, Major Earthquakes and Tsunamis in Chile during the period 1535 to 1955: Geologische Rundschau, v. 59, p. 938-960.

Lomnitz, C., 2004, Major earthquakes of Chile: A historical survey, 1535-1960: Seismological Research Letters, v. 75, p. 368-378.

Melnick, D., Bookhagen, B., Strecker, M.R., and Echtler, H.P., 2009, Segmentation of megathrust rupture zones from fore-arc deformation patterns over hundreds to millions of years, Arauco peninsula, Chile: Journal of Geophysical Research-Solid Earth, v. 114.

Metois, M., Socquet, A., and Vigny, C., 2012, Interseismic coupling, segmentation and mechanical behavior of the central Chile subduction zone: Journal of Geophysical ResearchSolid Earth, v. 117.

Moernaut, J., De Batist, M., Heirman, K., Van Daele, M., Pino, M., Brümmer, R., and Urrutia, R., 2009, Fluidization of burried mass-wasting deposits in lake sediments and its relevance for paleoseismology: Results from a reflection seismic study of lakes Villarrica and Calafquén (South-Central Chile): Sedimentary Geology, v. 213, p. 121-135.

Monecke, K., Anselmetti, F.S., Becker, A., Sturm, M., and Giardini, D., 2004, The record of historic earthquakes in lake sediments of Central Switzerland: Tectonophysics, v. 394, p. 21-40.

Moreno, H., 2000, Mapa de Peligros del Volcán Villarrica, Regiones de la Araucanía y de Los Lagos: Servicio Nacional de Geología y Minería, Documento de Trabajo, $\mathrm{N}^{\circ} 17$, scale 1:75 000, 1 sheet.

Moreno, M., Melnick, D., Rosenau, M., Baez, J., Klotz, J., Oncken, O., Tassara, A., Chen, J., Bataille, K., Bevis, M., Socquet, A., Bolte, J., Vigny, C., Brooks, B., Ryder, L., Grund, V., Smalley, B., Carrizo, D., Bartsch, M., and Hase, H., 2012, Toward understanding tectonic control on the Mw 8.8 2010 Maule Chile earthquake: Earth and Planetary Science Letters, v. 321-322, p. 152-165. 
Naranjo, J.A., and Moreno, H., 2004, Laharic debris-flows from Villarrica Volcano, in L.E. Lara and J. Clavero (Editors), Villarrica Volcano $\left(39.5^{\circ} \mathrm{S}\right)$, Southern Andes, Chile: Servicio Nacional de Geología y Minería, p. 28-38.

Newhall, C.G., and Self, S., 1982, The Volcanic Explosivity Index (VEI) - An estimate of explosive magnitude for historical volcanism: Journal of Geophysical Research-Oceans and Atmospheres, v. 87 (NC2), p. 1231-1238.

Petit-Breuilh, M.E., 2004, La Historia Eruptiva De Los Volcanes Hispanoamericanos (Siglos XVI Al XX): El Modelo Chileno : Casa de los Volcanes, Servicio de publicaciones exmo. cabildo insular de Lanzarote, $435 \mathrm{p}$.

Rosenau, M., Melnick, D., and Echtler, H., 2006, Kinematic constraints on intra-arc shear and strain partitioning in the southern Andes between 38 degrees $\mathrm{S}$ and 42 degrees $\mathrm{S}$ latitude: Tectonics, v. 25, 16 p.

Ruegg, J.C., Rudloff, A., Vigny, C., Madariaga, R., de Chabalier, J.B., Campos, J., Kausel, E., Barrientos, S., and Dimitrov, D., 2009, Interseismic strain accumulation measured by GPS in the seismic gap between Constitucion and Concepcion in Chile: Physics of the Earth and Planetary Interiors, v. 175, p. 78-85.

Siebert, L., Simkin, T., and Kimberly, 2010, Volcanoes of the World - Third Edition. University of California Press, Berkeley and Los Angeles, California, 551 pp.

SHOA (Servicio Hidrográfico y Oceanográfico de la Armada de Chile), 1987, Lago Villarrica, scale 1:40 000, 1 sheet.

SHOA (Servicio Hidrográfico y Oceanográfico de la Armada de Chile), 2008, Lago Calafquén, scale 1:30 000, 1 sheet.

Stern, C., 2008, Holocene tephrochronology record of large explosive eruptions in the southernmost Patagonian Andes: Bulletin of Volcanology, v. 70, p. 435-454.

Stern, C.R., Moreno, H., López-Escobar, L., Clavero, J.E., Lara, L.E., Naranjo, J.A., Parada, M.A., and Skewes, M.A., 2007, Chilean Volcanoes, in T. Moreno and W. Gibbons (Editors), The Geology of Chile: The Geological Society of London, London, p. 147-178.

Strasser, M., Hilbe, M., and Anselmetti, F., 2011, Mapping basin-wide subaquatic slope failure susceptibility as a tool to assess regional seismic and tsunami hazards: Marine Geophysical Research, v. 32, p. 331-347.

Sturm, M., and Matter, A., 1978, Turbidites and varves in Lake Brienz (Switzerland): deposition of clastic detritus by density currents: Special Publications of the International Association of Sedimentologists, v. 2, p. 147-168.

Urrutia de Hazbún, R., and Lanza Lazcano, C., 1993, Catástrofes en Chile, 1541-1992: Editorial La Noria, Santiago, Chile, 440 p.

Vallance, J.W., 2000, Lahars, in Sigurdsson, H., Houghton, B., McNutt, S.R., Rymer, H., and Stix, J. (Editors), 2000, Encyclopedia of Volcanoes: Academic Press, p. 601- 616.

Volland, S., Sturm, M., Lukas, S., Pino, M., and Müller, J., 2007, Geomorphological and sedimentological evolution of a lake basin under strong volcano-tectonic influence: Lake Calafquén (South Central Chile): Quaternary International, v. 161, no. 1, p. 32-45.

von Gunten, L., Grosjean, M., Beer, J., Grob, P., Morales, A., and Urrutia, R., 2009, Age modeling of young non-varved lake sediments: methods and limits. Examples from two lakes in Central Chile: Journal of Paleolimnology, v. 42, p. 401-412. 
Wang, K., Hu, Y., Bevis, M., Kendrick, E., Smalley, R., and Lauria, E., 2007, Crustal motion in the zone of the 1960 Chile earthquake: Detangling earthquake-cycle deformation and forearc-sliver translation: Geochemistry Geophysics Geosystems, v. 8, 14 p.

Watt, S. F. L., Pyle, D. M., Mather, T. A., Martin, R. S., and Matthews, N. E., 2009, Fallout and distribution of volcanic ash over Argentina following the May 2008 explosive eruption of Chaiten, Chile: Journal of Geophysical Research-Solid Earth, v. 114, 11 p.

Watt, S. F. L., Pyle, D. M., Naranjo, J. A., Rosqvist, G., Mella, M., Mather, T. A., and Moreno, H., 2011, Holocene tephrochronology of the Hualaihue region (Andean southern volcanic zone, $\sim 42^{\circ} \mathrm{S}$ ), southern Chile: Quaternary International, v. 246, p. 324-343.

Witter, J.B., Kress, V.C., Delmelle, P., Stix, J., 2004, Volatile degassing, petrology, and magma dynamics of the Villarrica Lava Lake, Southern Chile: Journal of Volcanology and Geothermal Research, v. 134, p. 303-337. 


\section{FIGURES}

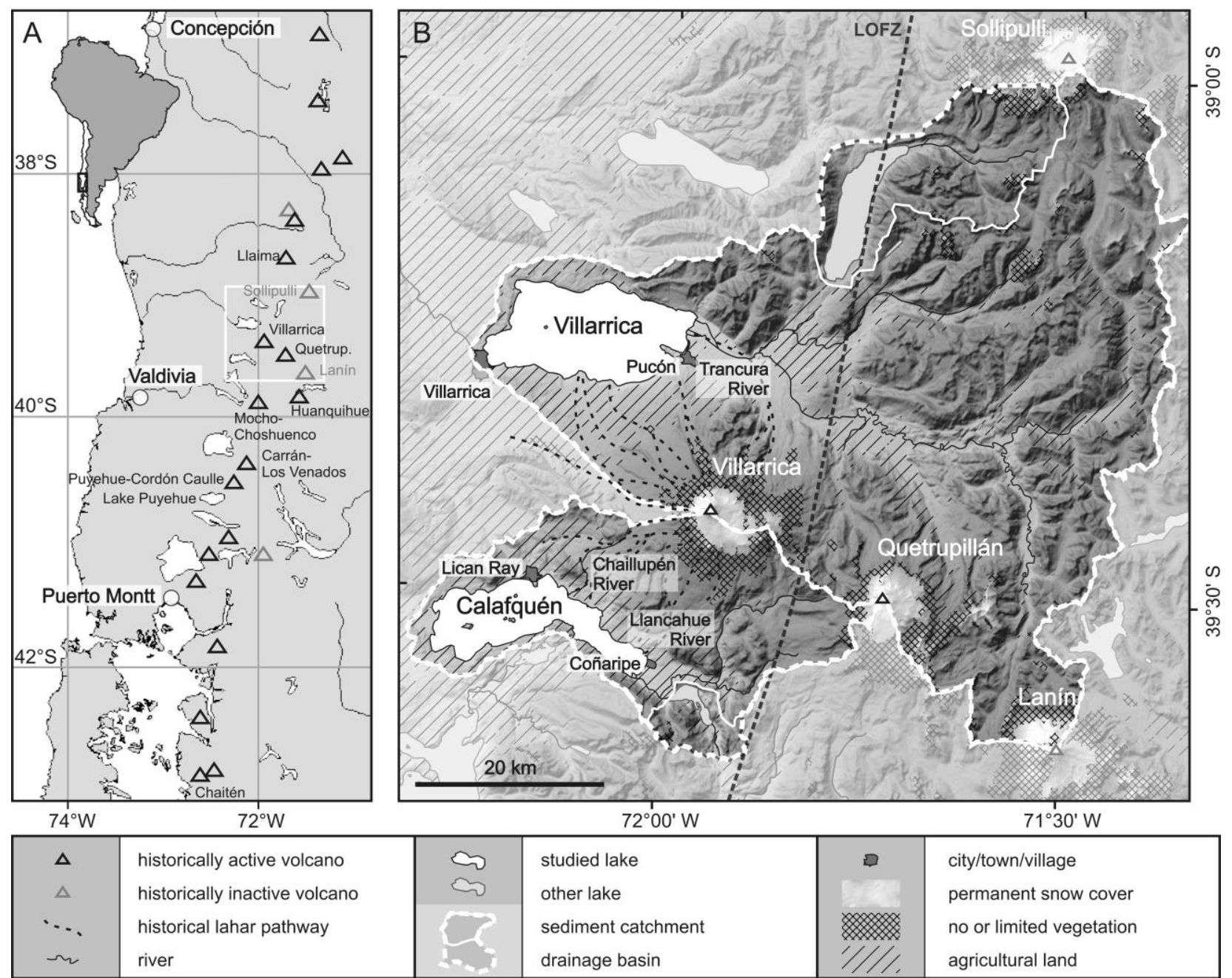

Figure 1: A) Geographic setting of the study area in South-Central Chile. B) The two studied lakes (black font) and their drainage basins and sediment catchments are indicated. Volcanoes within the lake catchments are indicated in white. Historically active (black triangles) and inactive (grey triangles) volcanoes in the region are indicated. Hatched areas indicate agricultural land; cross-hatched areas indicate zones with little or no vegetation and are found predominantly on the upper slopes of the volcanoes. Areas without additional indication are forested (based on Landsat7 Global Imagery). The main strand of the Liquiñe-Ofqui Fault Zone (LOFZ) is indicated with a transparent black dashed line (after Cembrano and Lara, 2009). 

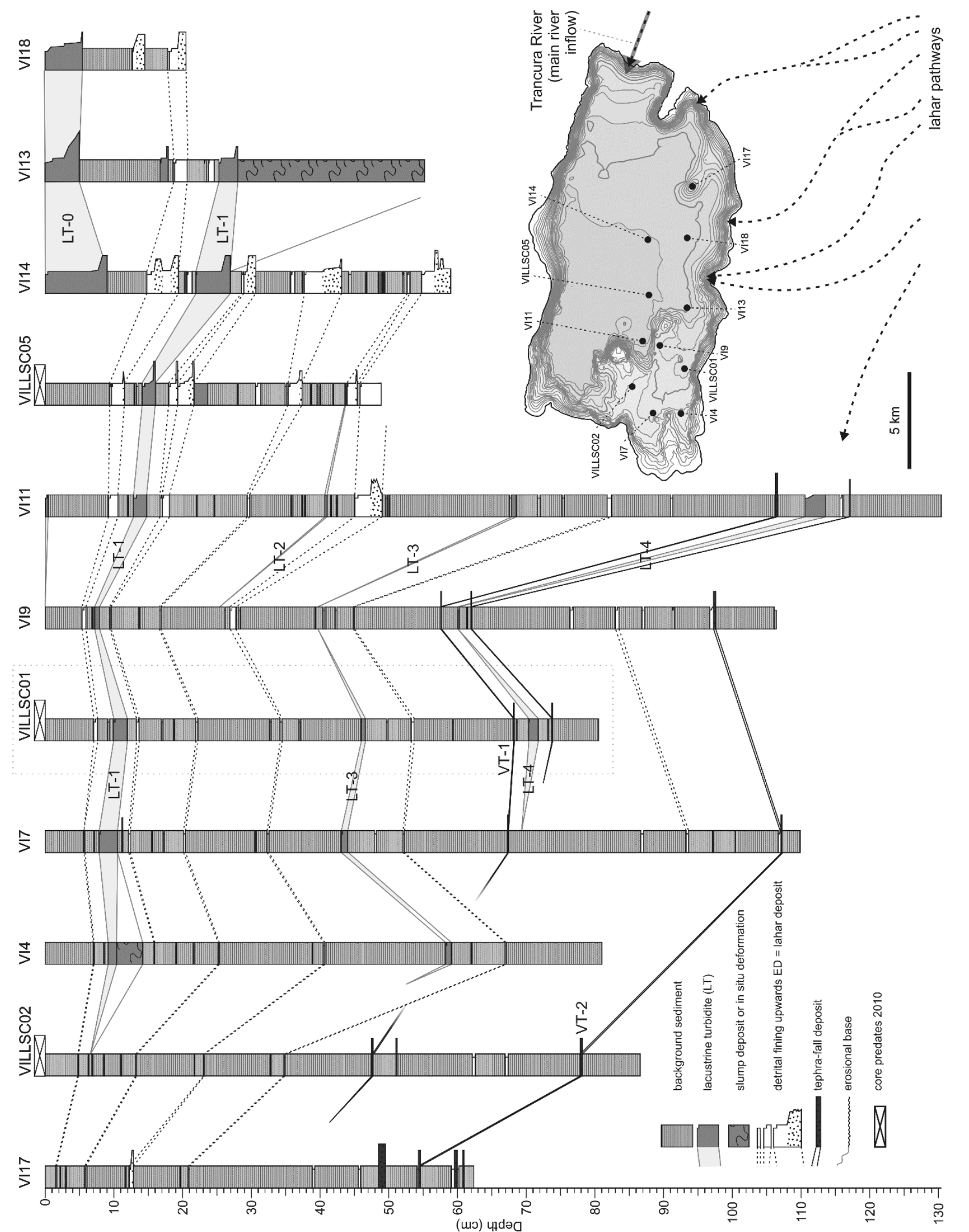

Figure 2: Lithologs of the sediment cores and correlation of the event deposits in Lake Villarrica. In the right hand corner the lake bathymetry with isobaths every $10 \mathrm{~m}$, core locations and lahar inflows. Dotted rectangle: master core; LT: lacustrine turbidite; VT: analyzed tephra-fall deposit. 


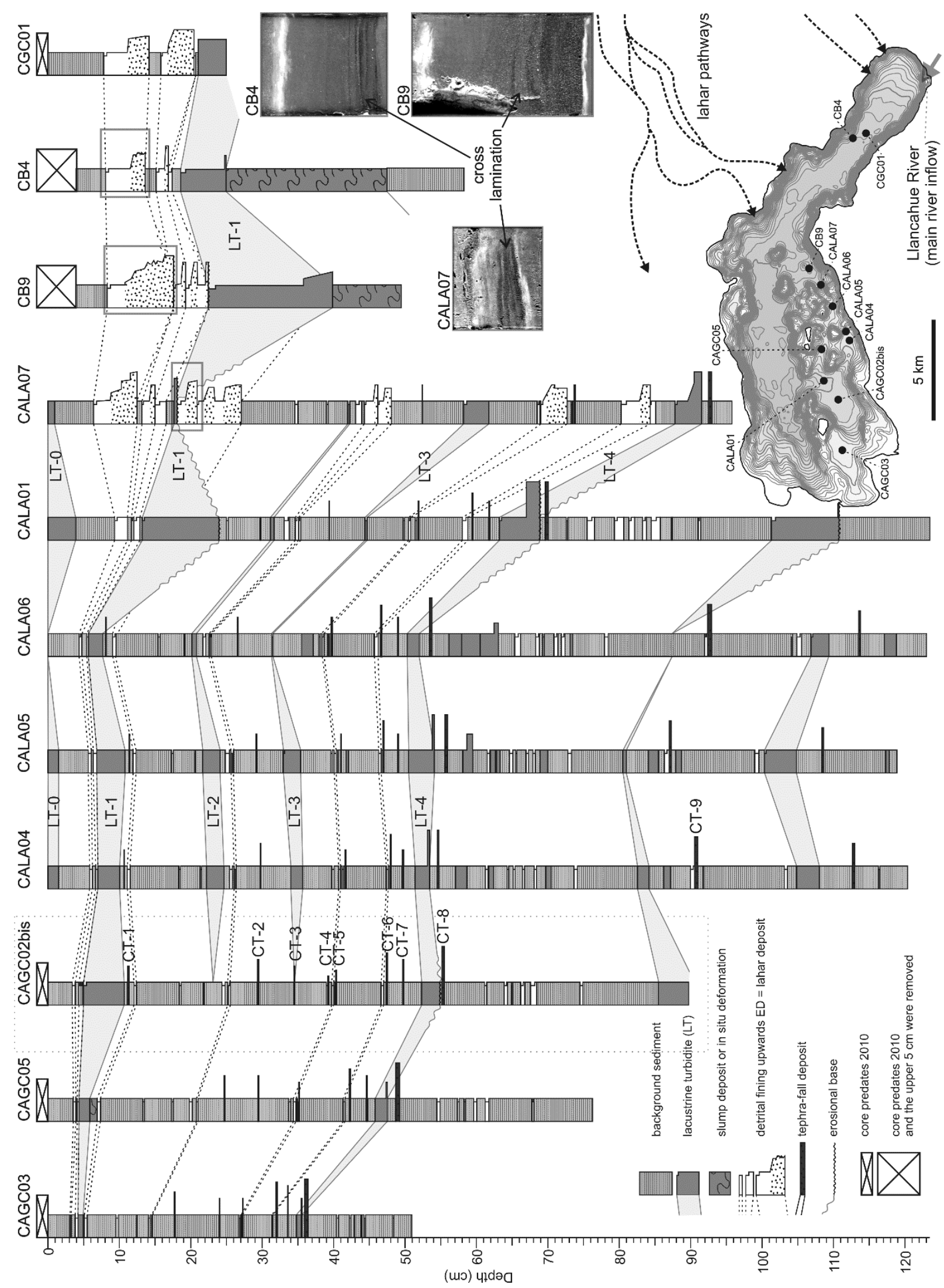

Figure 3: Lithologs of the sediment cores and correlation of the event deposits in Lake Calafquén. Locations of pictures on the right (zoom of a lahar deposit with indication of cross lamination) are indicated on the lithologs with a grey rectangle. In the right hand corner the lake bathymetry with isobaths every $10 \mathrm{~m}$, core locations and lahar inflows. Dotted rectangle: master core; LT: lacustrine turbidite; CT: analyzed tephra-fall deposit. 


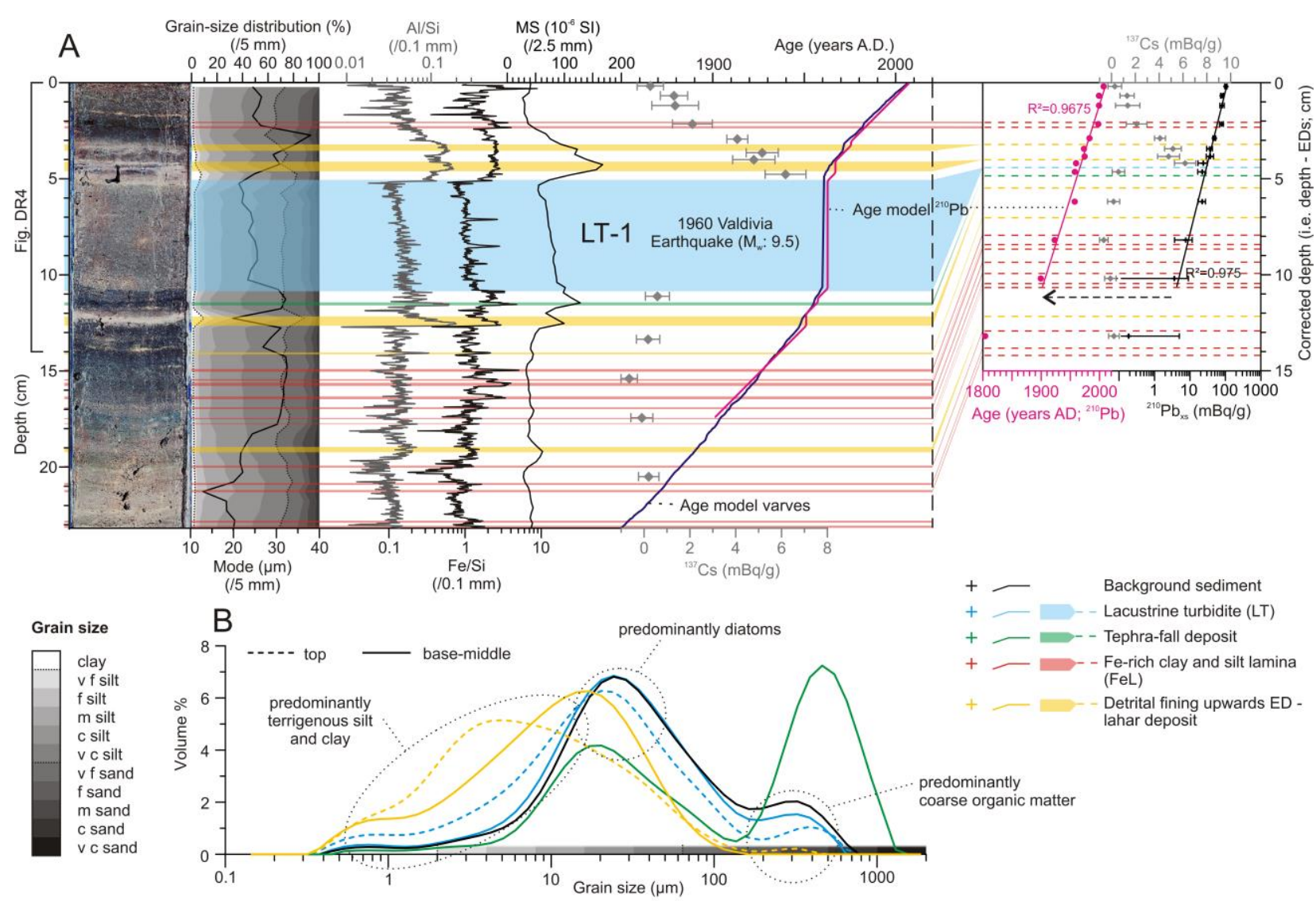

C

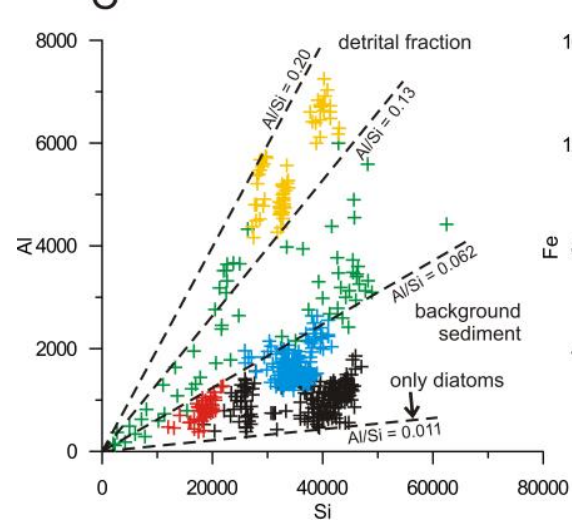

$\mathrm{D}$

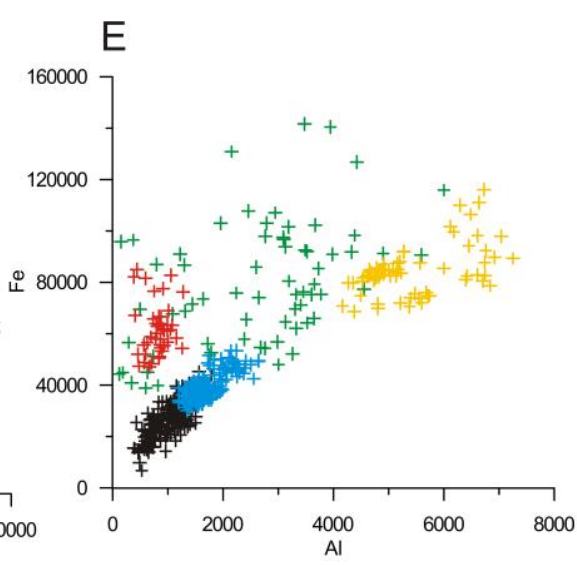

Figure 4: A: left: Picture of CAGC02bis, grain-size distribution, $\mu$ XRF ratios and magnetic susceptibility (MS). The four different types of EDs are indicated with colored transparent bars: lacustrine turbidites (LT; blue), tephra layers (green), Fe-rich clay and silt laminae (red) and detrital fining upwards EDs (yellow); right: Age model CAGC02bis for the last 150 years, based on ${ }^{137} \mathrm{Cs}$ (grey diamonds), ${ }^{210} \mathrm{~Pb}$ (pink line) and varve counts (dark blue line). B: Grain-size distribution of background sediment (black), tephra-fall deposits (green) and both base/middle (solid) and top (dashed) of detrital fining upwards EDs (yellow) and lacustrine turbidites (blue); C, D and E: $\mu$ XRF elemental counts in CAGC02bis of $\mathrm{Al}$ versus $\mathrm{Si}(\mathrm{C}), \mathrm{Fe}$ versus $\mathrm{Si}(\mathrm{D})$ and $\mathrm{Fe}$ versus $\mathrm{Al}(\mathrm{E})$, dashed lines represent elemental ratios differentiating between background sediment and EDs. 


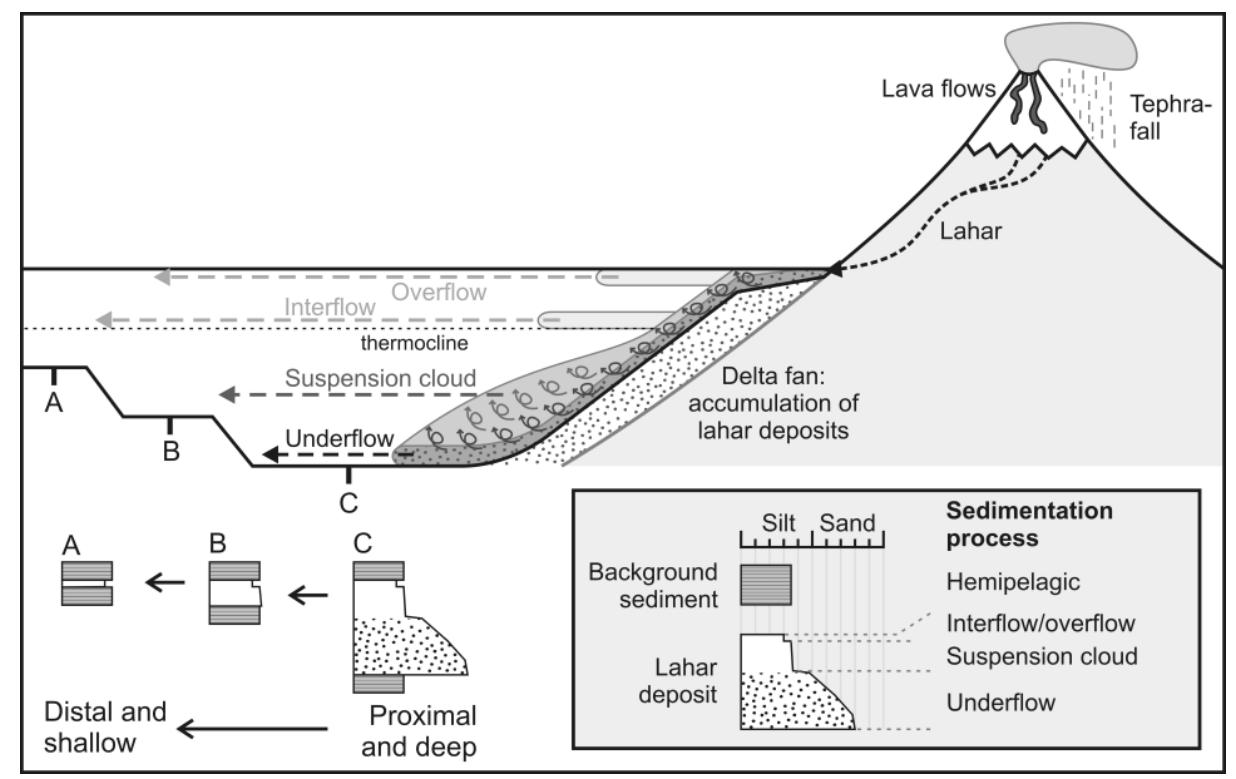

Figure 5: Schematic illustration of the formation of lahar deposits in lacustrine environments (after Sturm and Matter, 1978). When the lahar enters the lake, the coarsest grains (coarse silts and coarser) will be transported by an underflow and be deposited on deltaic fans and in (proximal) deep basins. Silt particles will go into suspension and form a suspension cloud that can transport particles further away and to shallower depths. The finest fraction gets transported over the entire lake by an overflow -when the lake is not stratified in winter- or by an interflow developing at the thermocline. Depending on the time of year the thermocline can occur at a depth a few meters (spring) to $\sim 70 \mathrm{~m}$ (autumn). 


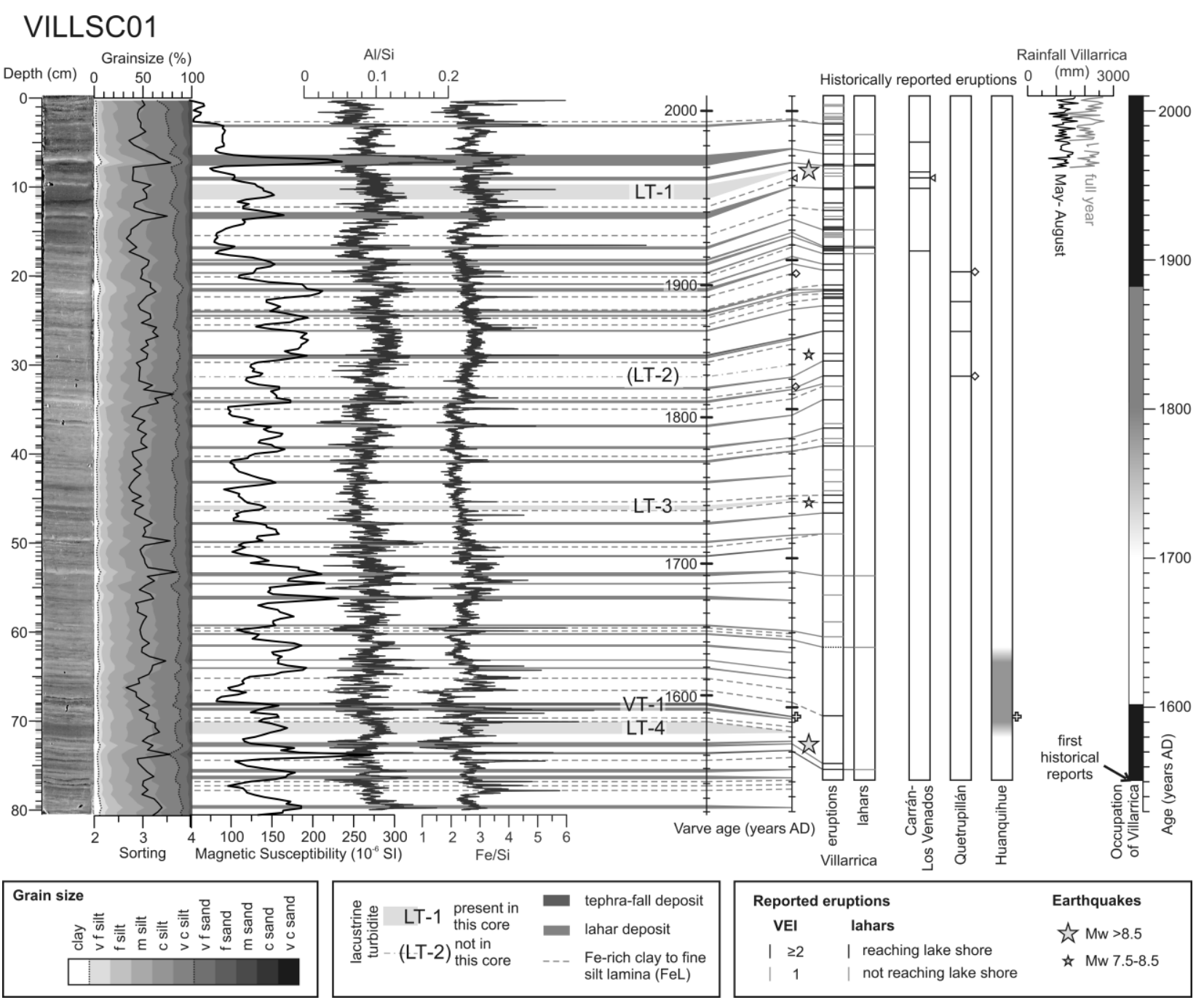

Figure 6: Picture, grain-size distribution, MS, $\mu$ XRF ratios and age model (varve counting) of core VILLSC01. EDs are projected on the age axis and, when possible, correlated with strong historical earthquakes in the region (stars) and eruptions at Villarrica Volcano, Quetrupillán Volcano (diamonds), the Carrán-Los Venados Volcanic Complex (triangles) and the Huanquihue Group (cross). Rainfall data from Villarrica since 1961 is also added for comparison (see Suppl. Fig. 1 for a more detailed graph of the rainfall data). LT: lacustrine turbidite; VT: analyzed tephra-fall deposit. 


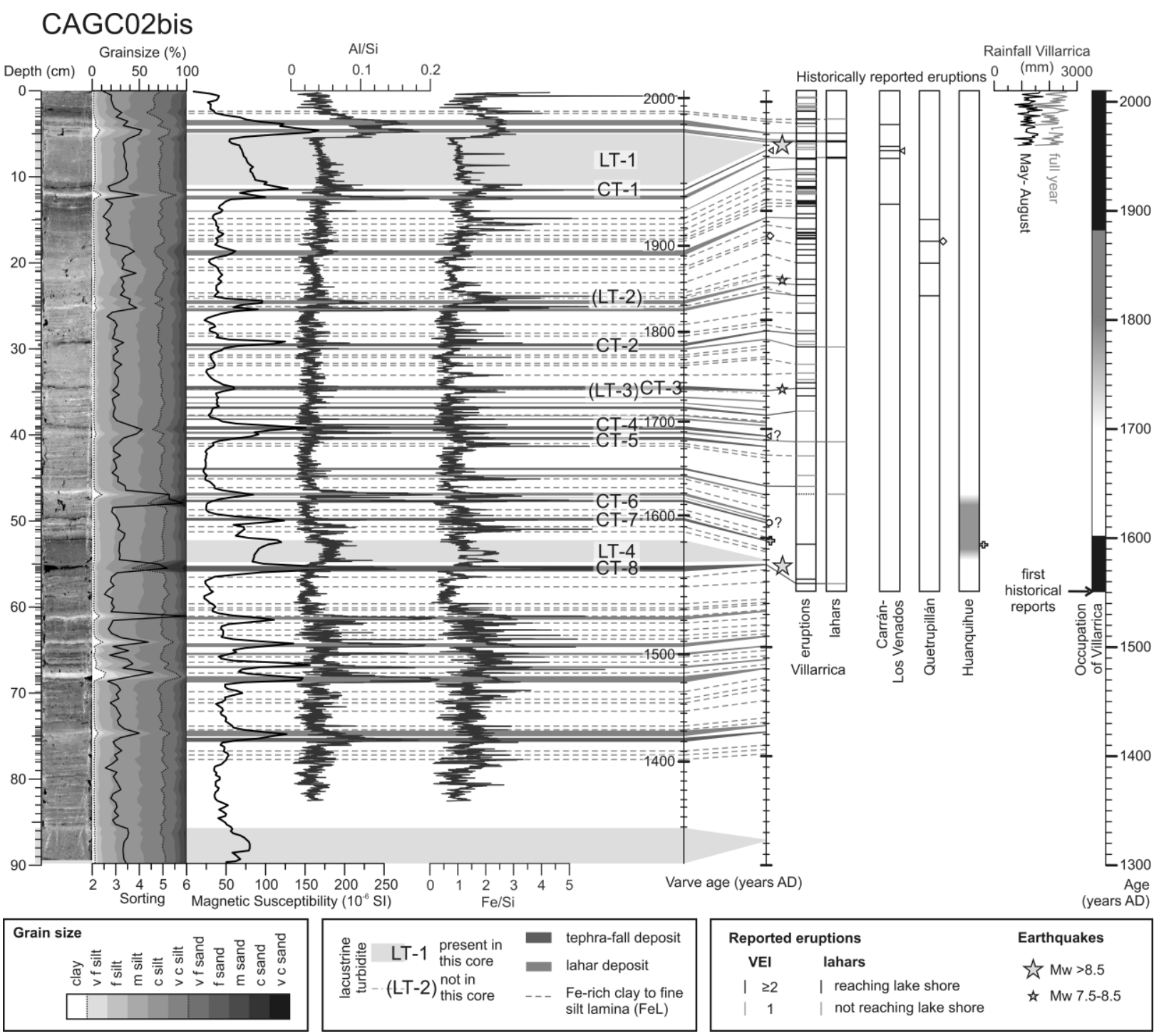

Figure 7: Picture, grain-size distribution, MS, $\mu$ XRF ratios and age model (varve counting) of core CAGC02bis. EDs are projected on the age axis and, when possible, correlated with strong historical earthquakes in the region (stars) and eruptions of Villarrica Volcano, Quetrupillán Volcano (diamonds), the Carrán-Los Venados Volcanic Complex (triangles), Mocho-Choshuenco Volcano (circle) and the Huanquihue Group (cross). Rainfall data from Villarrica since 1961 is also added for comparison (see Suppl. Fig. 1 for a more detailed graph of the rainfall data). LT: lacustrine turbidite; CT: analyzed tephrafall deposit. 


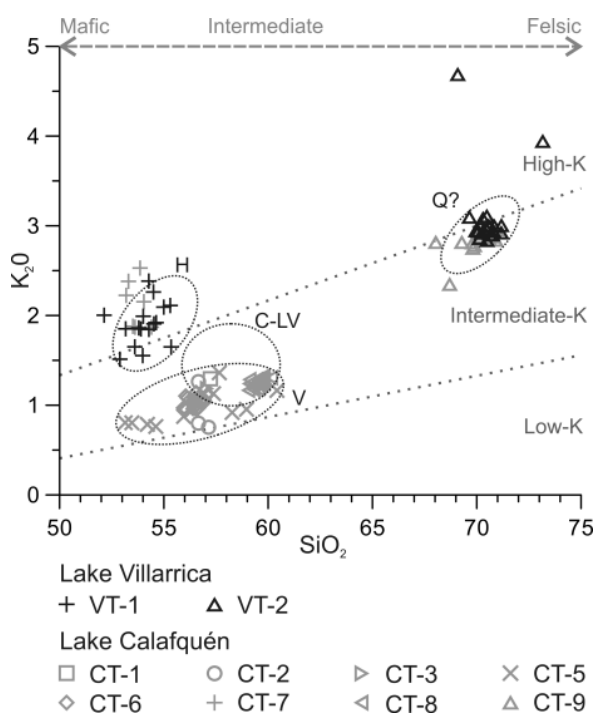

Figure 8: $\mathrm{K}_{2} \mathrm{O} / \mathrm{SiO}_{2}$ (wt \%) diagram of glass shards in the analyzed tephra-fall deposits in lakes Villarrica (black; location: Figs. 2 and 6) and Calafquén (dark grey; location: Figs. 3 and 7), and the inferred source volcanoes. Source volcanoes (dotted ovals): C-LV: Carrán-Los Venados (very recent coarse ash deposits); H: Huanquihue Group (scoria fall deposits of the c. 400 year old eruption of the Achen Ñiyeu cone); Q: Quetrupillán; V: Villarrica. K-divisions are taken from Gill (1981). 

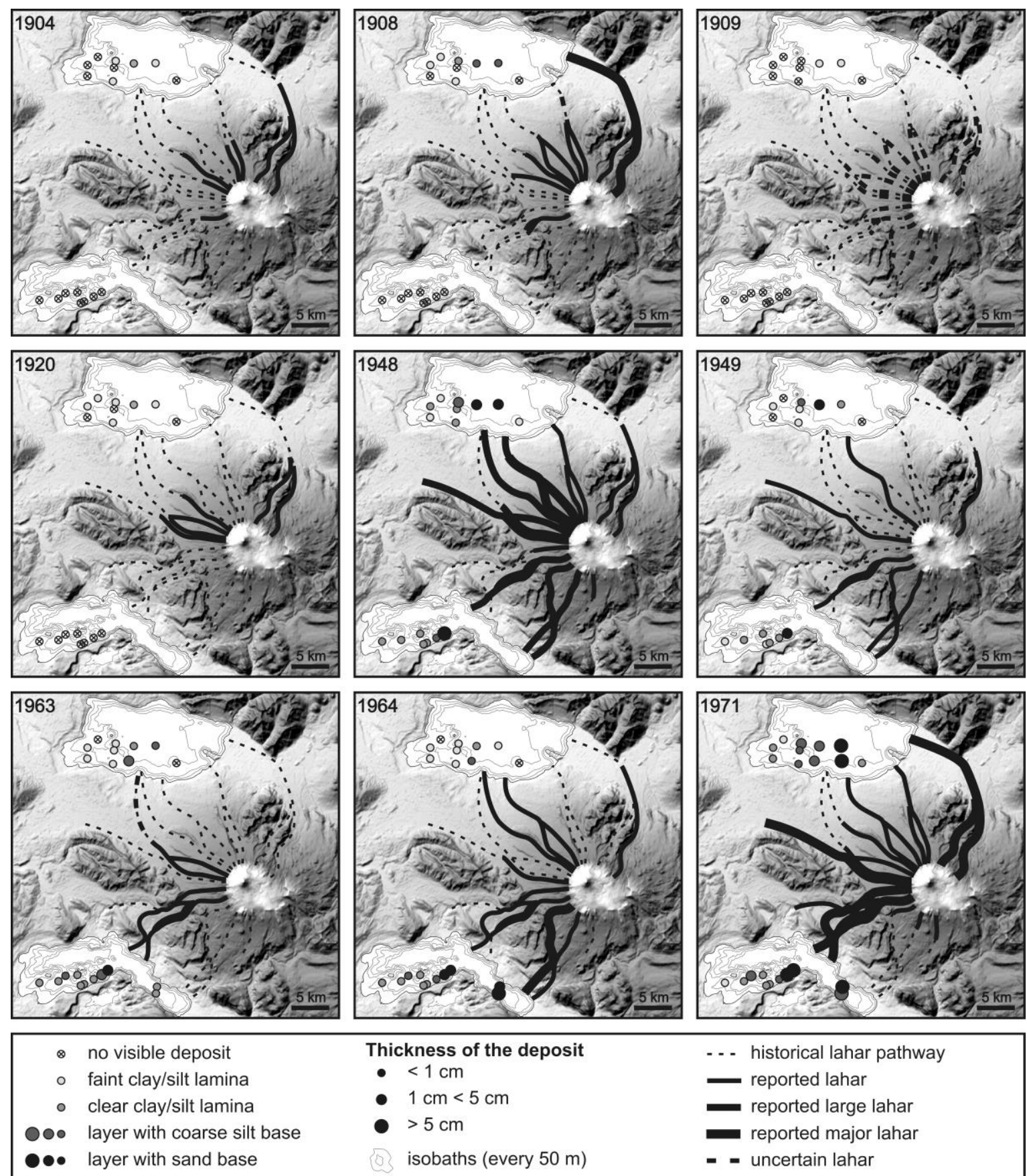
Thickness of the deposit
- $<1 \mathrm{~cm}$
- $1 \mathrm{~cm}<5 \mathrm{~cm}$
$>5 \mathrm{~cm}$
isobaths (every $50 \mathrm{~m}$ )

- - historical lahar pathway

reported lahar

reported large lahar

_ reported major lahar

- uncertain lahar

Figure 9: Historical lahar pathways compared with the thickness and maximum grain size of the linked lahar deposits. 


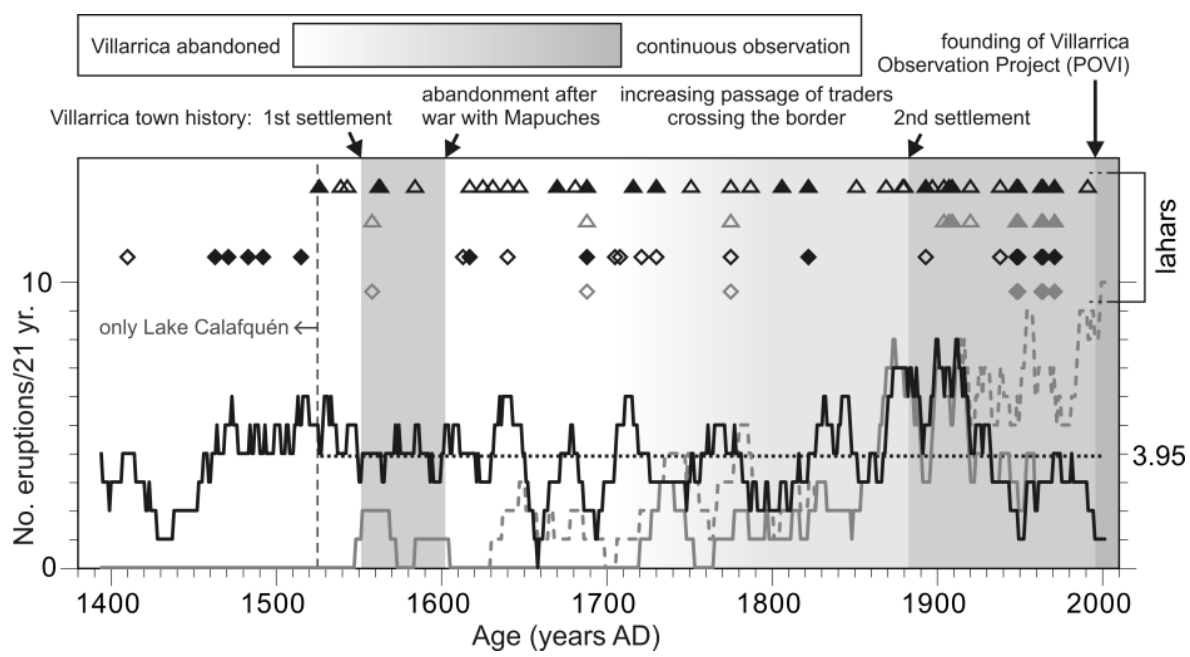

Figure 10: Eruption record of this study compared to historical records. Number of eruptions per 21 years according to this study (black solid line), historical reports (grey dashed line) and historical reports, considering only VEI $\geq 2$ events (grey solid line). Lahars towards Lake Villarrica and Lake Calafquén are indicated with a triangle and diamond, respectively (black: lahar deposits; grey: historical reports; filled: lahars reaching the lake shore; empty: not reaching the lake shore).

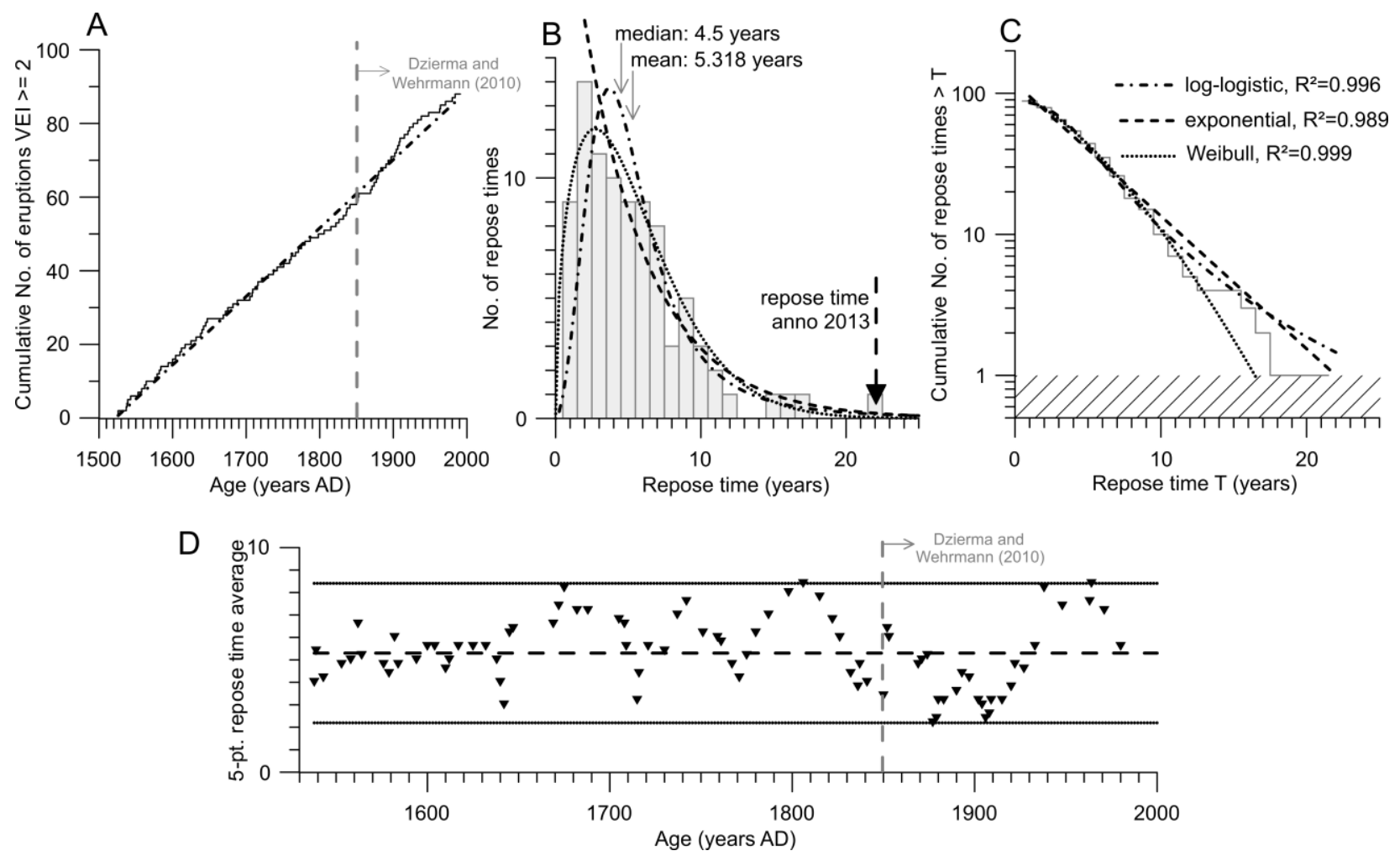

Figure 11: Statistical analyses of Villarrica-Volcano eruption (VEI $\geq 2)$ time series obtained in this study (1523 - 1991, the period for which both lakes provide a record), based on Dzierma and Wehrmann (2010). A: cumulative number of eruptions over the studied time period; B: histogram of repose times (time between 2 consecutive eruptions) and log-logistic (dash-dot), exponential (dashed) and Weibull (dotted) distributions; C: cumulative repose time distributions: log-logistic, exponential and Weibull; and D: test for stationarity: 5-point moving average of repose times over time (triangles) with mean (dashed line) and its $95 \%$ confidence interval (dotted line). 


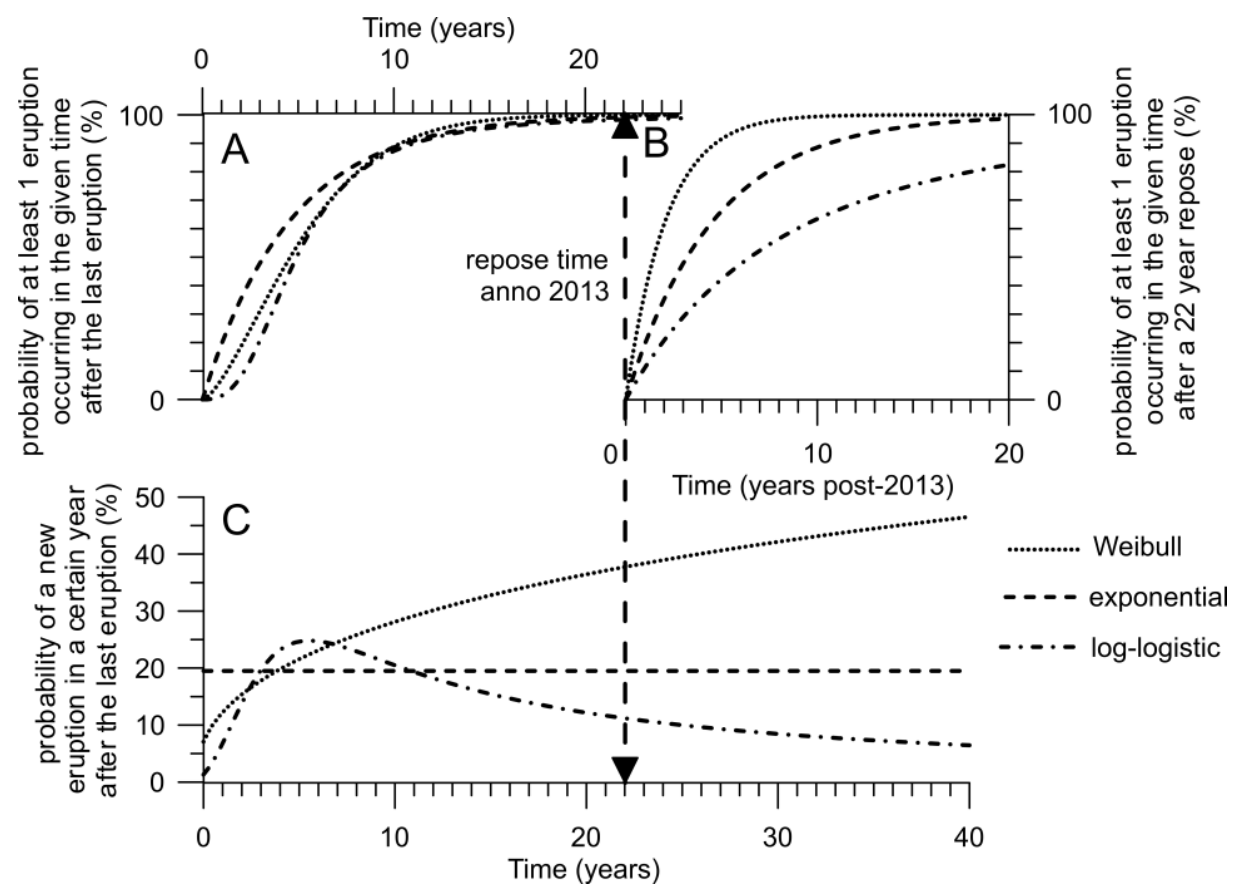

Figure 12: probability of at least one $\mathrm{VEI} \geq 2$ eruption occurring in the given time after A) the last eruption and B) a 22 year repose; C) probability of a new eruption in a certain year after the last eruption. 